University of Nebraska - Lincoln

DigitalCommons@University of Nebraska - Lincoln

\title{
Reduction of pertechnetate [Tc(VII)] by aqueous Fe(II) and the nature of solid phase redox products
}

John M. Zachara

Pacific Northwest National Laboratory, john.zachara@pnl.gov

Steve M. Heald

Pacific Northwest National Laboratory

Byong-Hun Jeon

Yonsei University

Ravi K. Kukkadapu

Pacific Northwest National Laboratory, ravi.kukkadapu@pnl.gov

Chongxuan Liu

Pacific Northwest National Laboratory

See next page for additional authors

Follow this and additional works at: https://digitalcommons.unl.edu/usdoepub

Part of the Bioresource and Agricultural Engineering Commons

Zachara, John M.; Heald, Steve M.; Jeon, Byong-Hun; Kukkadapu, Ravi K.; Liu, Chongxuan; Mckinley, James P.; Dohnalkova, Alice C.; and Moore, Dean A., "Reduction of pertechnetate [Tc(VII)] by aqueous $\mathrm{Fe}(\mathrm{II})$ and the nature of solid phase redox products" (2007). US Department of Energy Publications. 161. https://digitalcommons.unl.edu/usdoepub/161

This Article is brought to you for free and open access by the U.S. Department of Energy at DigitalCommons@University of Nebraska - Lincoln. It has been accepted for inclusion in US Department of Energy Publications by an authorized administrator of DigitalCommons@University of Nebraska - Lincoln. 


\section{Authors}

John M. Zachara, Steve M. Heald, Byong-Hun Jeon, Ravi K. Kukkadapu, Chongxuan Liu, James P. Mckinley, Alice C. Dohnalkova, and Dean A. Moore 


\title{
Reduction of pertechnetate [Tc(VII)] by aqueous Fe(II) and the nature of solid phase redox products
}

\author{
John M. Zachara ${ }^{\text {a,* }}$, Steve M. Heald ${ }^{\text {a,c }}$, Byong-Hun Jeon ${ }^{\mathrm{b}}$, Ravi K. Kukkadapu ${ }^{\mathrm{a}}$, \\ Chongxuan Liu ${ }^{a}$, James P. McKinley ${ }^{a}$, Alice C. Dohnalkova ${ }^{a}$, Dean A. Moore ${ }^{a}$ \\ ${ }^{a}$ Pacific Northwest National Laboratory, Richland, WA 99354, USA \\ b Yonsei University, Kangwon-Do 220-710, Republic of Korea \\ c Argonne National Laboratory, Argonne, IL 60439, USA
}

Received 19 April 2006; accepted in revised form 26 October 2006; available online 16 February 2007

\begin{abstract}
The subsurface behaviour of ${ }^{99} \mathrm{Tc}$, a contaminant resulting from nuclear fuels reprocessing, is dependent on its valence (e.g., IV or VII). Abiotic reduction of soluble $\mathrm{Tc}(\mathrm{VII})$ by $\mathrm{Fe}(\mathrm{II})_{(\mathrm{aq})}$ in $\mathrm{pH}$ 6-8 solutions was investigated under strictly anoxic conditions using an oxygen trap $\left(<7.5 \times 10^{-9}\right.$ atm $\left.\mathrm{O}_{2}\right)$. The reduction kinetics were strongly $\mathrm{pH}$ dependent. Complete and rapid reduction of $\mathrm{Tc}(\mathrm{VII})$ to a precipitated $\mathrm{Fe} / \mathrm{Tc}(\mathrm{IV})$ form was observed when $11 \mu \mathrm{mol} / \mathrm{L}$ of $\mathrm{Tc}(\mathrm{VII})$ was reacted with $0.4 \mathrm{mmol} / \mathrm{L} \mathrm{Fe}(\mathrm{II})$ at $\mathrm{pH} 7.0$ and 8.0, while no significant reduction was observed over 1 month at $\mathrm{pH}$ 6.0. Experiments conducted at $\mathrm{pH} 7.0$ with $\mathrm{Fe}(\mathrm{II})_{(\mathrm{aq})}=0.05-0.8 \mathrm{mmol} / \mathrm{L}$ further revealed that $\mathrm{Tc}(\mathrm{VII})$ reduction was a combination of homogeneous and heterogeneous reaction. Heterogeneous reduction predominated after approximately $0.01 \mathrm{mmol} / \mathrm{L}$ of $\mathrm{Fe}(\mathrm{II}) \mathrm{was}$ oxidized. The heterogeneous reaction was more rapid, and was catalyzed by $\mathrm{Fe}(\mathrm{II})$ that adsorbed to the $\mathrm{Fe} / \mathrm{Tc}(\mathrm{IV}) \mathrm{redox}$ product. Wet chemical and Fe-X-ray absorption near edge spectroscopy measurements (XANES) showed that Fe(II) and $\mathrm{Fe}(\mathrm{III})$ were present in the $\mathrm{Fe} / \mathrm{Tc}(\mathrm{IV})$ redox products after reaction termination. ${ }^{57} \mathrm{Fe}-\mathrm{Möss} b a u e r$, extended X-ray adsorption fine structure (EXAFS), and transmission electron microscopy (TEM) measurements revealed that the Fe/Tc(IV) solid phase was poorly ordered and dominated by $\mathrm{Fe}(\mathrm{II})$-containing ferrihydrite with minor magnetite. Tc(IV) exhibited homogeneous spatial distribution within the precipitates. According to Tc-EXAFS measurements and structural modeling, its molecular environment was consistent with an octahedral Tc(IV) dimer bound in bidentate edge-sharing mode to octahedral Fe(III) associated with surface or vacancy sites in ferrihydrite. The precipitate maintained $\mathrm{Tc}(\mathrm{IV})_{\mathrm{aq}}$ concentrations that were slightly below those in equilibrium with amorphous $\mathrm{Tc}(\mathrm{IV}) \mathrm{O}_{2} \cdot n \mathrm{H}_{2} \mathrm{O}_{(\mathrm{s})}$. The oxidation rate of sorbed Tc(IV) in the Fe/Tc precipitate was considerably slower than $\mathrm{Tc}(\mathrm{IV}) \mathrm{O}_{2} \cdot n \mathrm{H}_{2} \mathrm{O}_{(\mathrm{s})}$ as a result of its intraparticle/intragrain residence. Precipitates of this nature may form in anoxic sediments or groundwaters, and the intraparticle residence of sorbed/precipitated $\mathrm{Tc}(\mathrm{IV}) \mathrm{may}$ limit ${ }^{99} \mathrm{Tc}$ remobilization upon the return of oxidizing conditions.
\end{abstract}

(c) 2007 Elsevier Ltd. All rights reserved.

\section{INTRODUCTION}

${ }^{99}$ Technetium is a fission product of uranium-235 and plutonium-239 which poses a significant environmental hazard due to its long half-life $\left(t_{1 / 2}=2.13 \times 10^{5} \mathrm{yr}\right)$, abun-

\footnotetext{
* Corresponding author. Fax: +1 5093763650.

E-mail address: john.zachara@pnl.gov (J.M. Zachara).
}

dance in nuclear wastes, and environmental mobility under oxidizing conditions. The $\mathrm{Tc}(\mathrm{VII})$ valence state is stable in oxic environments and exists as the pertechnetate anion [Tc(VII) $\mathrm{O}_{4}^{-}$; (Wildung et al., 1979; Rard et al., 1999)] which is weakly sorbed by mineral material and forms few insoluble phases, with consequent high mobility in soil and groundwater. This form of ${ }^{99} \mathrm{Tc}$ is a risk-driving groundwater contaminant at some sites of nuclear reprocessing, such as the Hanford site in Washington State,

0016-7037/\$ - see front matter (c) 2007 Elsevier Ltd. All rights reserved. 
USA, and geochemical means are sought to reduce its mobility.

Tetravalent $\mathrm{Tc}[\mathrm{Tc}(\mathrm{IV})]$ is the stable valence state under reducing or anoxic conditions (e.g., $\mathrm{Eh}<0.1 \mathrm{~V}$ at $\mathrm{pH} 7$ ). $\mathrm{Tc}(\mathrm{IV})$ readily forms a sparingly soluble $\left(10^{-8.2} \mathrm{~mol} / \mathrm{L}\right)$, hydrated amorphous oxide precipitate $\left[\mathrm{Tc}(\mathrm{IV}) \mathrm{O}_{2} \cdot n \mathrm{H}_{2} \mathrm{O}_{(\mathrm{s})}\right.$; (Bondietti and Francis, 1979; Meyer et al., 1991; Burnett et al., 1995; Hess et al., 2004)], although carbonate complexation may enhance its solubility at higher $\mathrm{pH}$ depending on the alkalinity and $\mathrm{CO}_{2(\mathrm{~g})}$ pressure (Eriksen and Cui, 1991; Eriksen et al., 1993). The Tc(IV)/Tc(VII) couple bears similarity to the $\mathrm{Cr}(\mathrm{III}) / \mathrm{Cr}$ (VI) couple in terms of electron stoichiometry, oxyanion character of the higher valence state, and insolubility of the lower valence state $\left[\sim 10^{-7} \mathrm{~mol} / \mathrm{L}\right.$ for $\left.\mathrm{Cr}(\mathrm{III})(\mathrm{OH})_{3}\right]$. However, the chromium couple is more oxidizing:

$\mathrm{Cr}(\mathrm{VI}) \mathrm{O}_{4}{ }^{2-}+5 \mathrm{H}^{+}+3 \mathrm{e}^{-}=\mathrm{Cr}(\mathrm{III})(\mathrm{OH})_{3}(\mathrm{~s})+\mathrm{H}_{2} \mathrm{O} \quad E^{\mathrm{o}}=1.34 \mathrm{~V}$

$\mathrm{Tc}(\mathrm{VII}) \mathrm{O}_{4}{ }^{-}+4 \mathrm{H}^{+}+3 \mathrm{e}^{-}=\mathrm{Tc}(\mathrm{IV}) \mathrm{O}_{2} \cdot n \mathrm{H}_{2} \mathrm{O}(\mathrm{s})+(2-n) \mathrm{H}_{2} \mathrm{O} \quad E^{\mathrm{o}}=0.748 \mathrm{~V}$

Ferrous iron $[\mathrm{Fe}(\mathrm{II})]$ is an important reductant in anoxic sediments and groundwaters, and there is considerable interest in the reactivity of $\mathrm{Tc}(\mathrm{VII})$ with various $\mathrm{Fe}(\mathrm{II})$ forms because of the low solubility of the reduced state. Aqueous $\mathrm{Fe}(\mathrm{II})$ is reactive with $\mathrm{Cr}(\mathrm{VI}) \mathrm{O}_{4}{ }^{2-}$ (Eary and Rai, 1988; Buerge and Hug, 1997; Sedlak and Chan, 1997; Pettine et al., 1998; Wielinga et al., 2001) yielding a ferrihydrite-like, solid-solution product $\left[\mathrm{Cr}_{x} \mathrm{Fe}_{1-x}(\mathrm{OH})_{3}\right]$ that is less soluble than pure phase $\mathrm{Cr}(\mathrm{III})(\mathrm{OH})_{3(\mathrm{~s})}$ (Sass and Rai, 1987; Eary and Rai, 1988; Hansel et al., 2003a). In contrast, the homogeneous reduction of $\mathrm{Tc}(\mathrm{VII})$ by $\mathrm{Fe}(\mathrm{II})_{\mathrm{aq}}$, the subject of this paper, appears to proceed slowly or not at all, although the reaction is thermodynamically favourable in the circumneutral $\mathrm{pH}$ range (Cui and Eriksen, 1996a). Based on current understanding, the homogeneous redox reaction between $\mathrm{Fe}(\mathrm{II})$ and $\mathrm{Tc}(\mathrm{VII})$ can be written as follows under standard state conditions:

$$
\begin{aligned}
& \mathrm{Tc}(\mathrm{VII}) \mathrm{O}_{4}{ }^{-}+3 \mathrm{Fe}^{2+}+(n+7) \mathrm{H}_{2} \mathrm{O} \\
& \quad=\mathrm{Tc}(\mathrm{IV}) \mathrm{O}_{2} \cdot n \mathrm{H}_{2} \mathrm{O}_{(\mathrm{s})}+3 \mathrm{Fe}(\mathrm{OH})_{3(\mathrm{~s})}+5 \mathrm{H}^{+}
\end{aligned}
$$

with $\log \mathrm{K}(298)=-13.5$ [using data from Rard et al. (1999)]. The component stoichiometry demonstrates that the thermodynamic feasibility of the redox reaction between $\mathrm{Fe}(\mathrm{II})_{\mathrm{aq}}$ and $\mathrm{Tc}(\mathrm{VII}) \mathrm{O}_{4}{ }^{-}$is strongly determined by $\mathrm{pH}, \mathrm{Tc}(\mathrm{VII})$ and $\mathrm{Fe}(\mathrm{II})_{\mathrm{aq}}$ activity, and the nature and activity of the resulting solid phase redox products [e.g., $\mathrm{Fe}(\mathrm{OH})_{3(\mathrm{~s})}$ is assumed for simplicity of reaction stoichiometry]. The dominant aqueous $\mathrm{Fe}(\mathrm{II})$ species is $\mathrm{Fe}\left(\mathrm{H}_{2} \mathrm{O}\right)_{6}{ }^{2+}$ in acidic/neutral solutions with $\mathrm{pH}<7$. This species was found to be an ineffective reductant for $\mathrm{Tc}(\mathrm{VII})$ over a reaction time of seven days in the only reported study of homogeneous $\mathrm{Tc}(\mathrm{VII})$ reduction by $\mathrm{Fe}(\mathrm{II})_{\mathrm{aq}}$ (Cui and Eriksen, 1996a).

Biological $\mathrm{Tc}(\mathrm{VII})$ reduction by dissimilatory metal reducing bacteria (DMRB) has been proposed for in situ remediation of $\mathrm{Tc}(\mathrm{VII})$-contaminated subsurface environments in which $\mathrm{Fe}(\mathrm{III})$ oxides are in sufficient supply for DMRB growth and maintenance (http://www.lbl.gov/ nabir/). The microbiologic reduction of $\mathrm{Tc}(\mathrm{VII})$ and associated Tc immobilization via precipitation has been investigated in the laboratory (Lloyd and Macaskie, 1996; Lloyd et al., 2000; Wildung et al., 2000; Liu et al., 2002) and field (Istok et al., 2004). The bioreduction of Fe(III) oxides by DMRB in anoxic soils and sediments produces biogenic $\mathrm{Fe}$ (II) (aqueous and mineral) that may also function as an indirect/abiotic reductant for $\mathrm{Tc}(\mathrm{VII})$ and other redox sensitive metals and radionuclides (Fitzpatrick et al., 1978; Lloyd et al., 2000; Wielinga et al., 2001; Hansel et al., 2003a; Fredrickson et al., 2004; Jeon et al., 2004b; Wildung et al., 2004; Burke et al., 2006a). Remaining unclear are the relative rates of biotic $\mathrm{Tc}(\mathrm{VII})$ reduction as compared to the potentially parallel abiotic reaction pathways of homogeneous and heterogeneous Tc(VII) reduction.

During experimentation on heterogeneous $\mathrm{Tc}(\mathrm{VII})$ reduction (Fredrickson et al., 2004) we observed unexpected losses of $\mathrm{Tc}(\mathrm{VII})$ from selected $\mathrm{Fe}(\mathrm{II})_{\mathrm{aq}}-\mathrm{Tc}(\mathrm{VII})$ controls. Follow-up research in this communication was performed to evaluate the potential for homogeneous $\mathrm{Tc}(\mathrm{VII})$ reduction by $\mathrm{Fe}(\mathrm{II})_{\mathrm{aq}}$ under strictly anoxic conditions over a broader $\mathrm{pH}$ and concentration range than previously explored (Cui and Eriksen, 1996a). We observe that homogeneous reduction does occur at and above $\mathrm{pH} 7$, and that the reaction evolves to a heterogeneous one with reaction progress. A sparingly soluble $\mathrm{Fe} / \mathrm{Tc}$ precipitate is formed that is shown by X-ray absorption spectroscopy, Mössbauer spectroscopy, and transmission electron microscopy to have different characteristics than analogous ones resulting from homogeneous $\mathrm{Fe}(\mathrm{II})_{\mathrm{aq}}-\mathrm{Cr}(\mathrm{VI})$ reaction. The mixed $\mathrm{Fe} / \mathrm{Tc}$ precipitate maintains low $\mathrm{Tc}(\mathrm{IV})$ aqueous concentrations and slows Tc(IV) oxidation. These results provide important insights on the biogeochemical cycling of Tc in seasonally anoxic environments and the geochemical behaviour of Tc in contaminated subsurface environments associated with nuclear fuels reprocessing facilities (e.g., the Hanford Site, Washington State, USA).

\section{EXPERIMENTAL MATERIALS AND METHODS}

\subsection{Wet chemical experiments}

\subsubsection{Reduction}

Experiments were conducted in 125 or $200 \mathrm{~mL}$ glass serum reaction bottles (referred to as master reactors). Syringes, needles, glass vials, and plastic tubes were used for sample processing. Glassware and plastic bottles were acid washed with $1 \%$ nitric acid, rinsed several times with distilled and de-ionized water (DDW), and purged with $\mathrm{O}_{2}$-free $\mathrm{Ar} / \mathrm{H}_{2}$ (97:3) before use. Chemicals were reagent grade or better.

The reduction experiments were performed in a 97\% $\mathrm{Ar} / 3 \% \mathrm{H}_{2}$ atmosphere inside an anaerobic chamber (Forma Scientific, Marietta, $\mathrm{OH}$ ) that was equipped with a palladium catalyst to remove trace $\mathrm{O}_{2}$. Despite these precautions, it was discovered that the chamber contained up to $4 \times 10^{-7}$ atm $\mathrm{O}_{2}$ (corresponding to $0.29 \mathrm{ppm} \mathrm{O}_{2}$ in the chamber atmosphere) (Jeon et al., 2004a). The presence of this trace amount of $\mathrm{O}_{2}$ resulted in significant oxidation of $\mathrm{Fe}(\mathrm{II})$ in circumneutral $\mathrm{pH}$ solution. Consequently, all experiments with $\mathrm{Fe}(\mathrm{II})$ were conducted using 
a low-temperature oxygen trap that is described elsewhere (Jeon et al., 2004a). Briefly, the $\mathrm{O}_{2}$ trap consisted of bottles containing $0.90 \mathrm{mmol} / \mathrm{L} \quad \mathrm{Fe}(\mathrm{II})$ and $23.3 \mathrm{mmol} / \mathrm{L}$ $\mathrm{Fe}(\mathrm{III})$ as amorphous hydrous $\mathrm{Fe}(\mathrm{III})$ oxide (HFO). The $\mathrm{pH}$ was buffered at 8.1 with $0.1 \mathrm{M}$ Tris(hydroxymethyl)aminomethane (TRIS). The half-life for reduction of $\mathrm{O}_{2}$ in the suspension phase of the oxygen trap was less than $0.5 \mathrm{~s}$ and the half-life for transfer of $\mathrm{O}_{2}$ from the gas phase within the traps to the water phase was $6 \mathrm{~min}$. The oxygen trap removed $\mathrm{O}_{2}$ to strict anoxic conditions (i.e., $<7.5 \times 10^{-9}$ atm $\mathrm{O}_{2}$ ) (Jeon et al., 2004a) and was able to maintain $\mathrm{Fe}(\mathrm{II})$ in $\mathrm{pH} 7$ and 8 solutions for more than 2 weeks without any oxidation (Fig. 1).

DDW was purged with $\mathrm{O}_{2}$-free $\mathrm{Ar} / \mathrm{H}_{2}$ overnight and stored in the chamber for preparation of all solutions and suspensions. Stock solutions of 0.25 and $0.025 \mathrm{~mol} / \mathrm{L} \mathrm{Fe}(\mathrm{II})$ were prepared in the chamber from chloride salt in $0.1 \mathrm{~N}$ $\mathrm{HCl}$. These were stored in glass serum bottles that were wrapped in aluminum foil to exclude light. Isotopically enriched ${ }^{57} \mathrm{Fe}(\mathrm{II})$ stock solutions were also prepared in $0.1 \mathrm{~N}$ $\mathrm{HCl}$ from $96.7 \%$ pure ${ }^{57} \mathrm{Fe}(0)$ metal (Web Research Co., $\mathrm{MN})$ following the procedure suggested by Williams and Scherer (2004). ${ }^{99} \mathrm{Tc}$ was purchased as $\mathrm{NH}_{4} \mathrm{Tc}(\mathrm{VII}) \mathrm{O}_{4}$ (Perkin Elmer Life Sciences Inc., Boston, MA) and diluted in DDW to produce a $5 \mathrm{mmol} / \mathrm{L}$ stock solution. The stock solutions and acid/base were stored in serum bottles and were extensively deoxygenated using the oxygen trap before addition to the master reactors. All samples that contained $\mathrm{Fe}(\mathrm{II})$ were kept inside the chamber. The solution $\mathrm{pH}$ in master reactors, which was varied from 6 to 8 , was buffered using 10 or $30 \mathrm{mmol} / \mathrm{L} \mathrm{Na}-1,4$-piperazine $N, N^{\prime}$-bis 2ethanesulfonic acid (Na-PIPES). Solution $\mathrm{pH}$ was measured using an Orion $250 \mathrm{~A}+\mathrm{pH}$ meter with a combination $\mathrm{pH} /$ temperature probe.

Degassed Na-PIPES buffer solution was added to the master reactors, and then the reactors were capped with thick butyl rubber stoppers and crimp sealed. The master reactors were deoxygenated with $\mathrm{Ar} / \mathrm{H}_{2}$ flowed through the oxygen trap using a syringe and needle. After 7 days

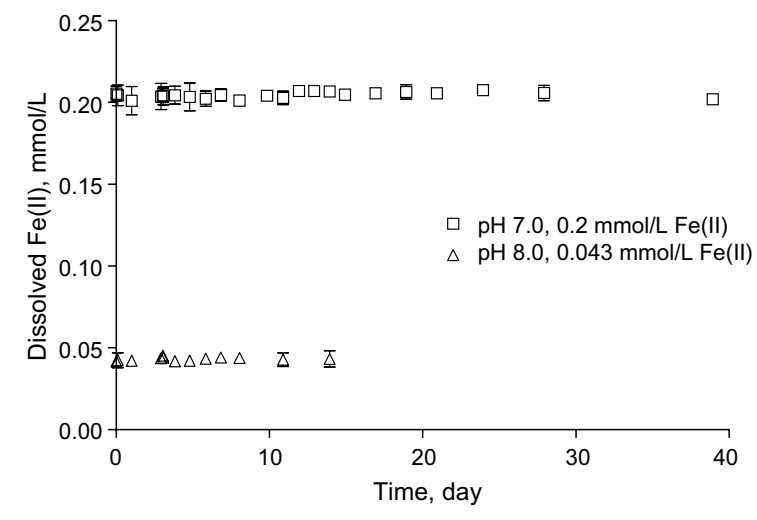

Fig. 1. Stability of $\mathrm{Fe}(\mathrm{II})_{\mathrm{aq}}$ in controls showing no oxidation for up to 40 days. The solutions were buffered by $10 \mathrm{mmol} / \mathrm{L}$ PIPES at $\mathrm{pH}$ $7[0.2 \mathrm{mmol} / \mathrm{L} \mathrm{Fe}(\mathrm{II})]$ and $8[0.043 \mathrm{mmol} / \mathrm{L} \mathrm{Fe}(\mathrm{II})]$. Fe(II) was introduced to the reactors after 7 days of extensive de-oxygenation with the $\mathrm{O}_{2}$ trap. Data represent means $( \pm \mathrm{SD})$ of triplicate samples. of extensive de-oxygenation of the reactors, Fe(II) solution was added first and monitored for 4 days for all experimental conditions to ensure the stability of the added Fe(II) against any oxidation or precipitation. Tc(VII) was added to the master reactor, and dissolved $\mathrm{Fe}$ (II) and $\mathrm{Tc}$ (VII) concentrations were monitored over time. In some experiments, isotopically enriched ${ }^{57} \mathrm{Fe}$ (II) was added to enable Mössbauer spectroscopic measurements on the small quantities of precipitate that resulted from the redox reaction. The solution was continuously and gently stirred using a Teflon coated magnetic stirring bar at room temperature. The conditions of the reduction experiments are summarized in Table 1.

\subsubsection{Oxidation}

The $\mathrm{Fe} / \mathrm{Tc}$ solid phase that was generated as a product in the reduction experiments was collected by centrifugation (10 min at $3000 \mathrm{rpm}$ ) at experiment termination and washed 3 times in the anaerobic chamber with deoxygenated $30 \mathrm{mmol} / \mathrm{L}$ Na-PIPES buffer solution at the desired $\mathrm{pH}(6.8,7.0$, and 8.0$)$ to remove unreacted $\mathrm{Fe}(\mathrm{II})_{(\mathrm{aq})}$. The solid was re-suspended in a sealed $50 \mathrm{~mL}$ Teflon centrifuge tube containing $25 \mathrm{~mL}$ deoxygenated $30 \mathrm{mmol} / \mathrm{L} \mathrm{Na}$ PIPES buffer solution. The suspension was subsequently oxygenated with compressed air that was bubbled through a water trap with a diffuser to saturate the air before entering the sample tube. The bubbling provided gentle mixing of the precipitate suspension. The kinetics of oxidative $\mathrm{Tc}$ (VII) dissolution were measured by monitoring dissolved Tc [presumed to be Tc(VII)] over time. The changes in solid/solution ratio due to sampling and evaporation were considered in the aqueous $\mathrm{Tc}(\mathrm{VII})$ calculation. The suspension $\mathrm{pH}$ changed by less than $0.05 \mathrm{pH}$ unit during the oxidation experiment.

\subsubsection{Wet chemical analytical techniques}

Samples for dissolved $\mathrm{Fe}(\mathrm{II})$ were filtered $(0.2 \mu \mathrm{m}$ syringe filter) and $0.1-0.5 \mathrm{~mL}$ of the filtrate was added to $5 \mathrm{~mL}$ of ferrozine reagent $(1 \mathrm{~g} / \mathrm{L}$ ferrozine in $50 \mathrm{mmol} / \mathrm{L}$ Hepes buffer, $\mathrm{pH}$ 7.0) in the anaerobic chamber. After

Table 1

Summary of experimental conditions and results

\begin{tabular}{|c|c|c|c|c|c|}
\hline $\begin{array}{l}\text { Reactor } \\
\text { No. }\end{array}$ & $\mathrm{pH}$ & $\begin{array}{l}{[\mathrm{Fe}(\mathrm{II})]^{\mathrm{a}}} \\
(\mathrm{mmol} / \mathrm{L})\end{array}$ & $\begin{array}{l}\mathrm{Fe}(\mathrm{OH})^{+, \mathrm{b}} \\
(\mu \mathrm{mol} / \mathrm{L})\end{array}$ & $\begin{array}{l}E_{\mathrm{H}} \\
(\mathrm{V})\end{array}$ & $\begin{array}{l}t^{1 / 2 \mathrm{~d}} \\
\text { (day) }\end{array}$ \\
\hline 1 & $6.0( \pm 0.2)$ & 0.4 & 0.09 & 0.028 & $\overline{N^{c}}$ \\
\hline 2 & $6.8( \pm 0.1)$ & 0.4 & 0.58 & 0.107 & 2.4 \\
\hline 3 & $7.0( \pm 0.1)$ & 0.05 & 0.12 & 0.073 & 22.7 \\
\hline 4 & $7.0( \pm 0.1)$ & 0.1 & 0.23 & 0.091 & 9.7 \\
\hline 5 & $7.0( \pm 0.1)$ & 0.2 & 0.46 & 0.109 & 3.1 \\
\hline 6 & $7.0( \pm 0.1)$ & 0.4 & 0.91 & 0.126 & 1.9 \\
\hline 7 & $7.0( \pm 0.1)$ & 0.6 & 1.37 & 0.137 & 0.90 \\
\hline 8 & $7.0( \pm 0.1)$ & 0.8 & 1.82 & 0.144 & 0.85 \\
\hline 9 & $8.0( \pm 0.2)$ & 0.4 & 8.90 & 0.225 & $<.25$ \\
\hline \multicolumn{6}{|c|}{$\begin{array}{l}{ }^{\mathrm{a}} \text { Added } \mathrm{Fe}(\mathrm{II}) \text {. } \\
{ }_{\mathrm{b}} \text { Combined concentration of both } \mathrm{Fe}(\mathrm{OH})^{+} \text {and } \mathrm{Fe}(\mathrm{OH})_{2}{ }^{\circ} \text { (aq) } \\
\text { species calculated using MINTEQA2 (Allison et al., 1998). } \\
{ }^{\mathrm{c}} \text { No apparent reaction. } \\
{ }^{\mathrm{d}} \text { Experimental half-life for the overall reaction (homogeneous } \\
\text { plus heterogeneous). }\end{array}$} \\
\hline
\end{tabular}


$15 \mathrm{~min}$, the samples were removed and the absorbance at $562 \mathrm{~nm}$ was determined with a Shimadzu UV-1240 spectrophotometer. Samples for dissolved Tc were filtered $(0.2 \mu \mathrm{m})$ and $1 \mathrm{~mL}$ of the filtrate was added to $9 \mathrm{~mL}$ anoxic scintillation cocktail in the anaerobic chamber and ${ }^{99} \mathrm{Tc}$ concentration was analyzed with a Packard 2500TR liquid scintillation counter (Packard Instrument Co. Meriden, CT, USA). The 10-mL samples were each counted for 20 min. The PIPES buffer at different $\mathrm{pH}$ values without ${ }^{99} \mathrm{Tc}$ spike was also counted to determine the counting background and a minimum detectable ${ }^{99} \mathrm{Tc}$ concentration. Background counts in the unspiked buffer were $\mathrm{pH}$ independent and averaged $(n=8) 21.9 \pm 0.903 \mathrm{dpm} / \mathrm{mL}$. These background counts defined a minimum detectable ${ }^{99} \mathrm{Tc}$ concentration of $5.9 \pm 0.24 \times 10^{-9} \mathrm{~mol} / \mathrm{L}$. Aqueous Tc concentrations were calculated from the total counts in $\mathrm{dpm} / \mathrm{mL}$ minus the background $(21.9 \mathrm{dpm} / \mathrm{mL})$.

\subsection{Transmission electron microscopy (TEM)}

Specimens for TEM analysis were prepared at the conclusion of the experiments (2-4 weeks) in the anaerobic chamber by applying $1 \mu \mathrm{L}$ of suspension onto a 200 mesh $\mathrm{Cu}$ grid with a formvar support film coated with carbon. The solids were allowed to settle for $1 \mathrm{~min}$, after which the clear liquid was gently blotted with a filter paper. The grid was dried in the anaerobic chamber. Imaging and analyses were performed using a JEOL 2010 High resolution TEM equipped with a $\mathrm{LaB}_{6}$ filament operated at $200 \mathrm{kV}$ with a nominal resolution of $1.8 \AA$. Images were digitally collected using a Gatan Digital Micrograph. Electron diffraction patterns were interpreted using JADE software (MDI, Livermore, CA). For comparison of specimen patterns with standards data, electron diffraction ring patterns were calculated from X-ray powder diffraction (PDF) data retrieved from a standards library (ICDD, 2003). The calculations were parameterized by fitting an electron diffraction pattern for sputtered gold (calculated from PDF 04-0784) to a sputtered gold pattern collected at the same time as the specimen patterns. The fitting was constrained by minimizing the difference between observed and theoretical d-spacings. The elemental composition of the precipitates was determined using the standard "semi-quantitative" data reduction software associated the instruments energy-dispersive spectroscopy (EDS) system (Oxford Instruments).

\section{3. ${ }^{57} \mathrm{Fe}$ Mössbauer spectroscopy}

Approximately $50 \mathrm{~mL}$ of $\mathrm{pH} 6.8,7.0,8.0$ suspensions were filtered $[0.2 \mu \mathrm{m}$ pore-size (Millipore); $1.25 \mathrm{~cm}$ diameter] to collect the mineral product. The filter and associated solids were subsequently dried under strictly anoxic conditions and embedded within epoxy (ITW Performance Polymers, Rivera Beach, Florida) in a brass Mössbauer sample holder $(0.95 \mathrm{~cm}$ by $1.27 \mathrm{~cm})$. The sample holder was sealed with scotch tape and an oxygen impermeable polymer (aluminized Mylar stable to $4 \mathrm{~K}$ ). The tape and polymer were snapped into the holder with rings made of carbonizedpolyethyletherketone (PEEK) polymer to ensure a tight fit. The sample holders (Mössbauer disk) were stored in the anoxic chamber until analysis.

Mössbauer spectra were collected using a $50 \mathrm{mCi}$ (initial strength) ${ }^{57} \mathrm{Co} / \mathrm{Rh}$ source. The velocity transducer MVT1000 (WissEL) was operated in a constant acceleration mode $(23 \mathrm{~Hz}, \pm 12 \mathrm{~mm} / \mathrm{s})$. An Ar-Kr proportional counter was used to detect the radiation transmitted through the holder, and the counts were stored in a multichannel scalar (MCS) as a function of energy (transducer velocity) using a 1024 channel analyzer. Data were folded to 512 channels to give a flat background and a zero-velocity position corresponding to the center shift (CS or $\delta$ ) of a metal iron foil at room temperature. Calibration spectra were obtained with a $25 \mu \mathrm{m}$ thick $\alpha-\mathrm{Fe}(\mathrm{m})$ foil (Amersham, England) placed in the same position as the samples to minimize any errors due to changes in geometry. A closed-cycle cryostat (ARS, Allentown, PA) was employed for 77 and $12 \mathrm{~K}$ measurements.

\subsection{X-ray absorption (XAS) spectroscopy}

\subsubsection{Mineral, valence, and speciation standards}

Various materials were used as reference phases for XANES and EXAFS analyses. Wustite $(\mathrm{FeO})$, hematite $\left(\alpha-\mathrm{Fe}_{2} \mathrm{O}_{3}\right)$, and magnetite $\left(\mathrm{Fe}_{3} \mathrm{O}_{4}\right)$ were obtained from commercial sources, while the preparation of other standards are described below.

$\mathrm{Tc}(\mathrm{IV}) \mathrm{O}_{2} \cdot n \mathrm{H}_{2} \mathrm{O}$ precipitate was prepared by the reduction of $\mathrm{Tc}(\mathrm{VII})$ to $\mathrm{Tc}(\mathrm{IV})$ using sodium ditihionite $\left(\mathrm{Na}_{2} \mathrm{~S}_{2} \mathrm{O}_{4}\right)$ inside a controlled atmospheric chamber (Hess et al., 2004). To reduce the Tc(VII) using the correct reductant to $\mathrm{Tc}(\mathrm{VII})$ ratio, $0.18 \mathrm{~mL}$ of $0.29 \mathrm{~mol} / \mathrm{L} \mathrm{Tc}(\mathrm{VII})$ was added to $4.12 \mathrm{~mL}$ of $0.195 \mathrm{~mol} / \mathrm{L} \mathrm{Na}_{2} \mathrm{~S}_{2} \mathrm{O}_{4}$. The $\mathrm{pH}$ was then adjusted to 12 using $\mathrm{NaOH}$. A black precipitate quickly formed which was aged for $72 \mathrm{~h}$. The precipitate was then washed 3 times using $20 \mathrm{~mL}$ of freshly prepared $0.01 \mathrm{~mol} / \mathrm{L} \mathrm{Na}_{2} \mathrm{~S}_{2} \mathrm{O}_{4}$ and then with anoxic deionzed water that had been scrubbed free of trace $\mathrm{O}_{2}$ using the oxygen trap. The remaining solid was collected by filtration and then dried in an oxygen-scrubbed dessicator in the glove box.

A stock suspension of 2-line ferrihydrite $\left(5 \mathrm{Fe}_{2} \mathrm{O}_{3} \cdot 9 \mathrm{H}_{2} \mathrm{O}\right.$; $500 \mathrm{mmol} / \mathrm{L}$ ) was prepared according to Cornell and Schwertmann (2000). The ferrihydrite suspension was allowed to age for $48 \mathrm{~h}$ inside the chamber. Excess $\mathrm{Na}$ and $\mathrm{NO}_{3}$ were removed from the ferrihydrite by dialysis in deionized water. The ferrihydrite concentration was determined by gravimetric and $\mathrm{Fe}$ analyses. Aliquots were dried under anoxic conditions for XAS standards yielding 5-6 line ferrihydrite according to $\mathrm{X}$-ray diffraction analysis.

A subsample of the $\mathrm{Tc}(\mathrm{IV}) \mathrm{O}_{2} \cdot n \mathrm{H}_{2} \mathrm{O}$ precipitate $(20 \mathrm{mg}$ of ${ }^{99} \mathrm{Tc}$ ) was added to $900 \mathrm{~mL}$ of $2 \mathrm{~mol} / \mathrm{L} \mathrm{HCl}$ and allowed to dissolve to steady state. The Tc(IV) solution was filtered through a $0.45-\mu \mathrm{m}$ filter under anoxic conditions and the ${ }^{99} \mathrm{Tc}$ concentration quantified in the filtrate. A Tc(IV)/ferrihydrite coprecipitate reference phase with 1 mole $\%$ $\mathrm{Tc}(\mathrm{IV})$ was prepared by mixing a predetermined volume of acidic Tc(IV) solution with an appropriate volume of ferrihydrite suspension; this mixing lead to the dissolution of all of the ferrihydrite. The acidic $\mathrm{Tc}(\mathrm{IV}) / \mathrm{Fe}(\mathrm{III})$ solution 
was then adjusted to $\mathrm{pH}=7$ ( $<1 \mathrm{~h})$ to form the coprecipitate. The resulting solid was aged for $2 \mathrm{~h}$, washed with deoxygenated, deionized water, and dried under strictly anoxic conditions. The dried solid yielded an X-ray diffraction pattern of 2-line ferrihydrite with hints of a 6-line structure. The dried solid was subsequently dissolved in acid for quantitative analysis of $\mathrm{Fe}$ and $\mathrm{Tc}$ concentrations.

\subsubsection{XAS methods}

Extended X-ray adsorption fine structure (EXAFS) measurements were made at the Advanced Photon Source (APS) sector 20 beamlines, 20-ID and 20-BM on the $\mathrm{Fe} / \mathrm{Tc}$ precipitates isolated from the $\mathrm{pH} 7.0$ and $\mathrm{pH} 8.0$ homogeneous reduction experiments by filtration and dried from ethanol in the anoxic glove box. A Si (111) monochromator was used with a 1-mm entrance slit located approximately $50 \mathrm{~m}$ from the source on both beamlines. The monochrometer allowed an energy resolution of about $1 \mathrm{eV}$ at the Fe edge and about $4 \mathrm{eV}$ at the Tc edge. The Fe edge measurements were made on beamline 20-BM using the dried $\mathrm{Fe} / \mathrm{Tc}$ precipitates (or standards) that were mixed with vacuum grease or boron nitride. The samples were prepared and maintained under strictly anaerobic conditions using gases that were passed through the oxygen trap described in Section 2.1.1. The sample cells were sealed in teflon holders with two layers of Kapton. At the beamline, the reduced samples were kept under flowing nitrogen to avoid any oxygen diffusion through the Kapton. Data were taken in transmission mode with a $\mathrm{Fe}$ foil used for online energy calibration. The Fe edge was calibrated to better than $0.1 \mathrm{eV}$, allowing for an approximate error of $5 \%$ in the determination of $\mathrm{Fe}(\mathrm{II}) / \mathrm{Fe}$ (III) valence ratios based on near edge fits. The $\mathrm{Tc}(\mathrm{IV})$ standards $\left[\mathrm{Tc}(\mathrm{IV}) \mathrm{O}_{2} \cdot n \mathrm{H}_{2} \mathrm{O}\right.$; and Tc(IV) coprecipitated with ferrihydrite] were mixed with boron nitride in a sample holder and stored under anoxic conditions. These were also measured on 20-BM.

The Tc X-ray absorption measurements (XANES and EXAFS) were performed on the Fe/Tc precipitates that were embedded in epoxy for Mössbauer spectroscopy (Section 2.3). These were measured on beamline 20-ID in fluorescence mode using a 13-element Ge fluorescence detector. A total of 12 scans were run for each sample to improve the signal to noise ratio. A Mo foil was used for energy calibration.

The EXAFS and XANES data were analyzed using the Athena and Artemis interfaces to the IFEFFIT program package (Ravel and Newville, 2005). For the near edge analysis, the valence was obtained using linear combination fits of normalized standard spectra to the normalized data. Similar linear combinations fits were also made as appropriate for the EXAFS spectra. When more detailed modeling was required, theoretical models were calculated using FEFF 7 (Rehr and Albers, 2000) with the parameters refined using ARTEMIS.

\section{RESULTS}

\subsection{Abiotic $\mathrm{Tc}(\mathrm{VII})$ reduction by $\mathrm{Fe}(\mathrm{II})$}

The use of the oxygen trap allowed us to synthesize and maintain solutions of $\mathrm{Fe}(\mathrm{II})_{\mathrm{aq}}$ and $\mathrm{Tc}(\mathrm{VII})$ that were func- tionally devoid of contaminant oxygen. The absence of contaminant oxygen was displayed by the long term stability of ferrous iron controls at $\mathrm{pH} 7$ and 8 (Fig. 1), and the four day stability of $\mathrm{Fe}(\mathrm{II})_{\mathrm{aq}}$ solutions before spiking with Tc(VII) (Figs. 2 and 3b). The Tc(VII) solutions were presumed to be oxygen free by analogy because they were treated identically to those with only $\mathrm{Fe}(\mathrm{II})_{\mathrm{aq}}$. Thus, Tc(VII) was the only oxidant of consequence in the experiments with the $\mathrm{Fe}(\mathrm{II})-\mathrm{Tc}(\mathrm{VII})$ mixtures.

The abiotic reduction of $\mathrm{Tc}(\mathrm{VII})$ was measured by its loss from solution. Reduction of $\mathrm{Tc}(\mathrm{VII})$ to $\mathrm{Tc}(\mathrm{IV})$ was rapid when $11 \mu \mathrm{mol} / \mathrm{L}$ of $\mathrm{Tc}(\mathrm{VII})$ was reacted with $0.4 \mathrm{mmol} / \mathrm{L}$ $\mathrm{Fe}(\mathrm{II})_{\mathrm{aq}}$ at $\mathrm{pH} 7.0$, and almost instantaneous at $\mathrm{pH} 8.0$ (Fig. 2). In contrast, no significant reduction was observed for up to 2 weeks of reaction time at $\mathrm{pH}$ 6.0. Extended monitoring of $\mathrm{Tc}(\mathrm{VII})$ in $\mathrm{pH} 6.0$ solution for more than 1 month still showed no reaction. The data therefore verified that the reduction reaction was strongly $\mathrm{pH}$ dependent as shown in Eq. (3). Complete reduction of added Tc(VII) was observed within $1 \mathrm{~h}$ in a solution at $\mathrm{pH} 8.0$, accompanied with the rapid decrease in dissolved $\mathrm{Fe}(\mathrm{II})_{\mathrm{aq}}$ from 0.40 to $0.36 \mathrm{mmol} / \mathrm{L}$ within $1 \mathrm{~h}$ and eventually to $0.33 \mathrm{mmol} / \mathrm{L}$ $\mathrm{Fe}(\mathrm{II})_{\mathrm{aq}}$ after 14 days of reaction time (Fig. 2b). Careful wet chemical analysis indicated that the total amount of $\mathrm{Fe}(\mathrm{II})_{\mathrm{aq}}$ loss from solution was higher than the
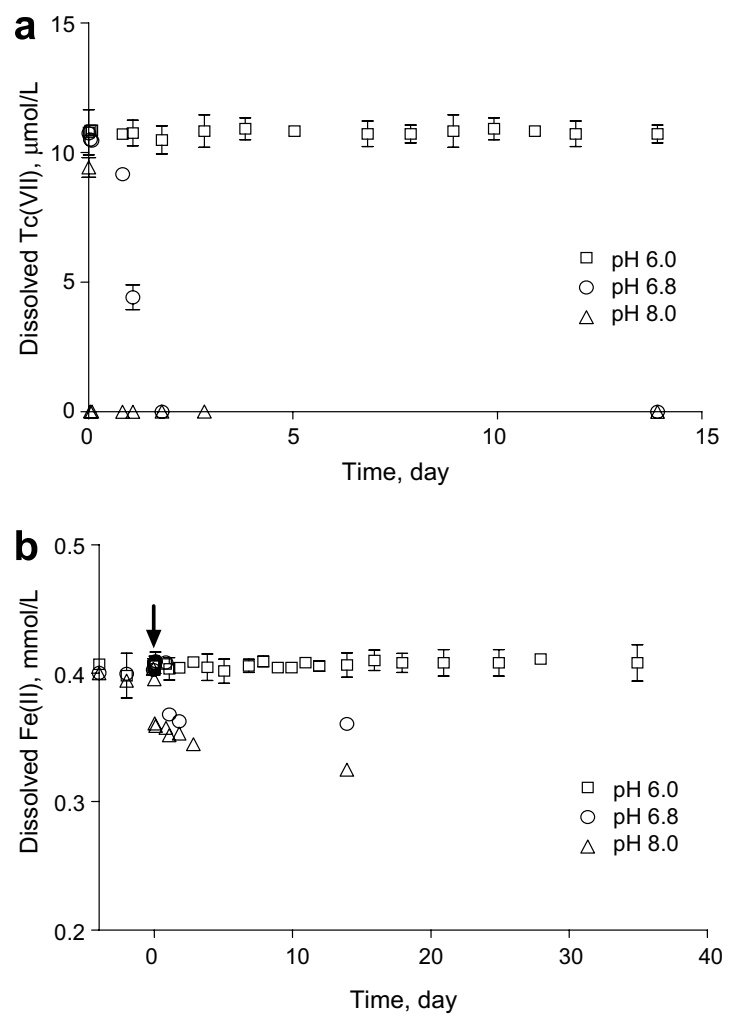

Fig. 2. (a) Abiotic reduction of $\mathrm{Tc}(\mathrm{VII})$ by $\mathrm{Fe}(\mathrm{II})_{\mathrm{aq}}$ and (b) recovery of added $\mathrm{Fe}(\mathrm{II})_{\mathrm{aq}}$ from the $10 \mathrm{mmol} / \mathrm{L}$ PIPES buffer solutions at different $\mathrm{pH}$ values. $[\mathrm{Tc}(\mathrm{VII})]_{\mathrm{added}}=11 \mu \mathrm{mol} / \mathrm{L}$, and $[\mathrm{Fe}(\mathrm{II})]_{\text {added }}=0.4 \mathrm{mmol} / \mathrm{L}$. Data represent means $( \pm \mathrm{SD})$ of triplicate samples. The arrow in (b) represents the time at which $\mathrm{Tc}(\mathrm{VII})$ was spiked into the $\mathrm{Fe}(\mathrm{II})_{\mathrm{aq}}$ solution. 

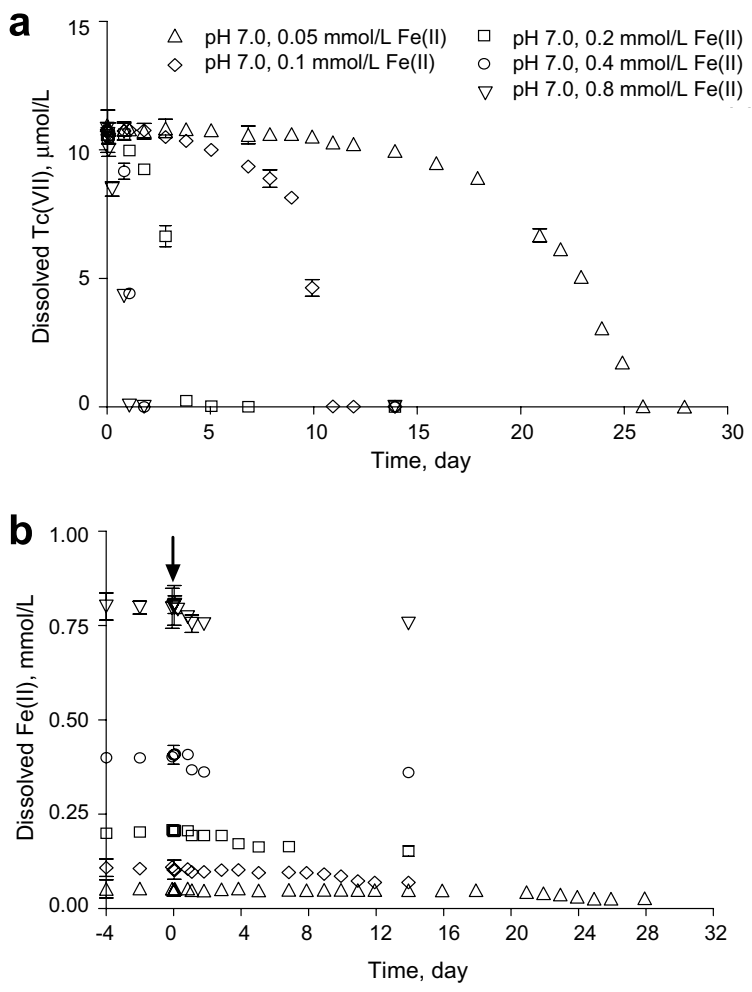

Fig. 3. (a) Abiotic reduction of $\mathrm{Tc}(\mathrm{VII})$ by $\mathrm{Fe}(\mathrm{II})_{\mathrm{aq}}$ and (b) recovery of added $\mathrm{Fe}(\mathrm{II})_{\mathrm{aq}}$ from the $10 \mathrm{mmol} / \mathrm{L}$ PIPES buffer solutions for different total $\mathrm{Fe}(\mathrm{II})$ concentrations at $\mathrm{pH}$ 7.0. $[\mathrm{Tc}(\mathrm{VII})]_{\mathrm{added}}=11 \mu \mathrm{mol} / \mathrm{L}$, and $\left[\mathrm{Fe}(\mathrm{II})_{\mathrm{aq}}\right]_{\mathrm{added}}=0.05-0.8 \mathrm{mmol} /$ L. Arrow indicates time of Tc(VII) addition. Data represent means $( \pm \mathrm{SD})$ of triplicate samples.

stoichiometric demand for complete reduction of $\mathrm{Tc}(\mathrm{VII})$ to $\mathrm{Tc}(\mathrm{IV})(\mathrm{Fe} / \mathrm{Tc}=3$; Table 2$)$, implying sorption of $\mathrm{Fe}(\mathrm{II})_{\mathrm{aq}}$ by the solid phase product of the redox reaction (adsorption to or precipitation within). There was no significant change in $\mathrm{pH}$ in any of the experiments. Magnetite is thermodynamically the most stable iron phase given the experimental $\mathrm{Fe}(\mathrm{II}) / \mathrm{Fe}(\mathrm{III})$ ratio, solution composition, computed $E_{\mathrm{H}}$ (Table 1), and $\mathrm{pH}$ value (Jolivet et al., 1992; Tronc et al., 1992; Jeon et al., 2003). The reduction of $\mathrm{Tc}(\mathrm{VII})$ in $\mathrm{pH} 7.0$ solution was completed within 2 days by $0.40 \mathrm{mmol} / \mathrm{L} \mathrm{Fe}(\mathrm{II})_{\mathrm{aq}}$, and an excess in Fe removal from the aqueous phase was again observed.

Given the expected influence of $\mathrm{Fe}(\mathrm{II})_{\mathrm{aq}}$ concentration on the Tc(VII) reduction rate as implied by Eq. (3), experiments were performed over a range of $\mathrm{Fe}(\mathrm{II}): \mathrm{Tc}(\mathrm{VII})$ ratios at pH 7.0 (Fig. 3). The results obtained for the $0.05 \mathrm{mmol} / \mathrm{L}$ $\mathrm{Fe}(\mathrm{II})$ system were in good agreement with previous obser-

Table 2

Elemental composition of the precipitates determined by wet chemical analysis

\begin{tabular}{llllll}
\hline Reactor No. & $\mathrm{pH}$ & {$[\mathrm{Fe}(\mathrm{II})](\mathrm{mmol} / \mathrm{L})$} & $\mathrm{Fe}(\%)$ & $\mathrm{Tc}(\%)$ & $\mathrm{Fe} / \mathrm{Tc}$ \\
\hline 2 & 6.8 & 0.4 & 85.5 & 14.5 & 5.89 \\
6 & 7.0 & 0.4 & 85.8 & 14.2 & 6.04 \\
9 & 8.0 & 0.4 & 86.7 & 13.3 & 6.51 \\
\hline
\end{tabular}

vations made by Cui and Eriksen (1996a), who found that $\mathrm{Tc}(\mathrm{VII})$ was stable for up to a week in solutions containing 0.04-0.07 mmol/L Fe(II) aq at pH 7. However, Tc(VII) was reduced at increasingly rapid rate as the $\mathrm{Fe}(\mathrm{II})_{\mathrm{aq}}$ concentrations increased. The reduction of $\mathrm{Tc}(\mathrm{VII})$ was complete after 1 day when $\mathrm{Fe}(\mathrm{II})_{\mathrm{aq}}=0.8 \mathrm{mmol} / \mathrm{L}$. Moreover, the loss of $\mathrm{Tc}(\mathrm{VII})$ from solution showed complex kinetic behaviour in that the apparent reduction rate increased with reaction progress, accelerating markedly after the reduction of 1 $2 \mu \mathrm{mol} / \mathrm{L}$ of $\mathrm{Tc}(\mathrm{VII})$. This phenomena was most evident for $\mathrm{Fe}(\mathrm{II})_{\mathrm{aq}}=0.05$ and $0.1 \mathrm{mmol} / \mathrm{L}$ (Fig. 3a), but close inspection of the data showed its occurrence at higher $\mathrm{Fe}(\mathrm{II})_{\mathrm{aq}}$ concentrations as well. The reaction rate accelerated when solid-phase reaction products became evident as increased solution turbidity and the minor accumulation of dark sediment.

The final aqueous concentrations of ${ }^{99} \mathrm{Tc}$ were quantified in all experiments where $\mathrm{Tc}(\mathrm{VII})$ reduction proceeded to near completion [e.g., dissolved $\mathrm{Tc}(\mathrm{VII}) \approx 0$ in Figs. 2 and $3 \mathrm{a}]$. The results were independent of $\mathrm{pH}$ and $\mathrm{Fe}(\mathrm{II})$ concentration. The final, total counts averaged $35.0 \pm 4.7 \mathrm{dpm} /$ $\mathrm{mL} \quad(n=18)$. This value was above background $(21.9 \pm 0.903 \mathrm{dpm} / \mathrm{mL})$ and yielded a background corrected concentration of $3.5 \times 10^{-9} \mathrm{~mol} / \mathrm{L}\left(10^{-8.45} \mathrm{~mol} / \mathrm{L}\right)$ of ${ }^{99} \mathrm{Tc}$, presumed to exist as $\mathrm{Tc}(\mathrm{IV})_{\mathrm{aq}}$. The nominal solubility of $\mathrm{Tc}(\mathrm{IV}) \mathrm{O}_{2} \cdot n \mathrm{H}_{2} \mathrm{O}_{(\mathrm{s})}$ at circumneutral $\mathrm{pH}$ is reported to be $6.3 \times 10^{-9}\left(10^{-8.2} \mathrm{~mol} / \mathrm{L}\right)$ (Meyer et al., 1991; Rard et al., 1999; Hess et al., 2004).

\subsection{Kinetics and stoichiometry of $\mathrm{Tc}(\mathrm{VII})$ reduction}

The homogeneous reduction of $\mathrm{Cr}(\mathrm{VI})$ by $\mathrm{Fe}(\mathrm{II})$ has been described as (Fendorf and Li, 1996; Sedlak and Chan, 1997; Pettine et al., 1998):

$\mathrm{d}[\mathrm{Cr}(\mathrm{VI})] / \mathrm{d} t=-k[\mathrm{Cr}(\mathrm{VI})][\mathrm{Fe}(\mathrm{II})]^{n}$

where $k$ is a function of $\mathrm{Fe}(\mathrm{II})$ speciation and increases with the presence of the hydrolyzed species $\mathrm{FeOH}^{+}$and $\mathrm{Fe}(\mathrm{OH})_{2}{ }^{\circ}$, and $n$ is close to unity. Moreover, the rate behavior generally exhibits pseudo-first order decay $\left\{\mathrm{d}[\mathrm{Cr}(\mathrm{VI})] / \mathrm{d} t=-k_{1}[\mathrm{Cr}(\mathrm{VI})]\right.$; where $\left.k[\mathrm{Fe}(\mathrm{II})]^{n}=k_{1}\right\}$ for a given concentration of $\mathrm{Cr}(\mathrm{VI}), \mathrm{Fe}(\mathrm{II})$, and $\mathrm{pH}$. Under pseudo-first order conditions, plots of $\ln \left[C_{t} / C_{\mathrm{o}}\right]$ (where $C_{\mathrm{o}}$ is the initial concentration and $\mathrm{C}_{t}$ the concentration at time $=t$ ) versus time yield linear plots with slope of $-k_{1}$.

Pseudo-first order plots for the $\mathrm{Tc}(\mathrm{VII})$ reduction data in Figs. 2 and 3 demonstrated complex behavior as shown for $0.20 \mathrm{mmol} / \mathrm{L} \mathrm{Fe}$ (II) at pH 7 (Reactor 5 data, Fig. 4a). Three regions were observed that were termed: (i) homogeneous reaction, (ii) heterogeneous reaction, and (iii) reaction completion. All of the kinetic data exhibited variants of this behavior. The homogeneous region ended at a dramatic breakpoint after which the reaction rate for heterogeneous reduction increased markedly. At $\mathrm{pH} 7$, this breakpoint decreased in time with increased $\mathrm{Fe}(\mathrm{II})$ concentration, occurring at $23 \mathrm{~d}$ for $0.05 \mathrm{mmol} / \mathrm{L} \mathrm{Fe}(\mathrm{II}), 9 \mathrm{~d}$ for $0.1 \mathrm{mmol} / \mathrm{L}$ $\mathrm{Fe}(\mathrm{II}), 3 \mathrm{~d}$ for $0.2 \mathrm{mmol} / \mathrm{L}, 1 \mathrm{~d}$ for $0.4 \mathrm{mmol} / \mathrm{L}$, and $0.5 \mathrm{~d}$ for $0.6 \mathrm{mmol} / \mathrm{L}$. The homogeneous region was not evident for $0.8 \mathrm{mmol} / \mathrm{L} \mathrm{Fe}(\mathrm{II})$ at $\mathrm{pH} 7$, or for the $\mathrm{pH} 8$ data where $\mathrm{Tc}(\mathrm{VII})$ reduction was rapid. The breakpoints between the 

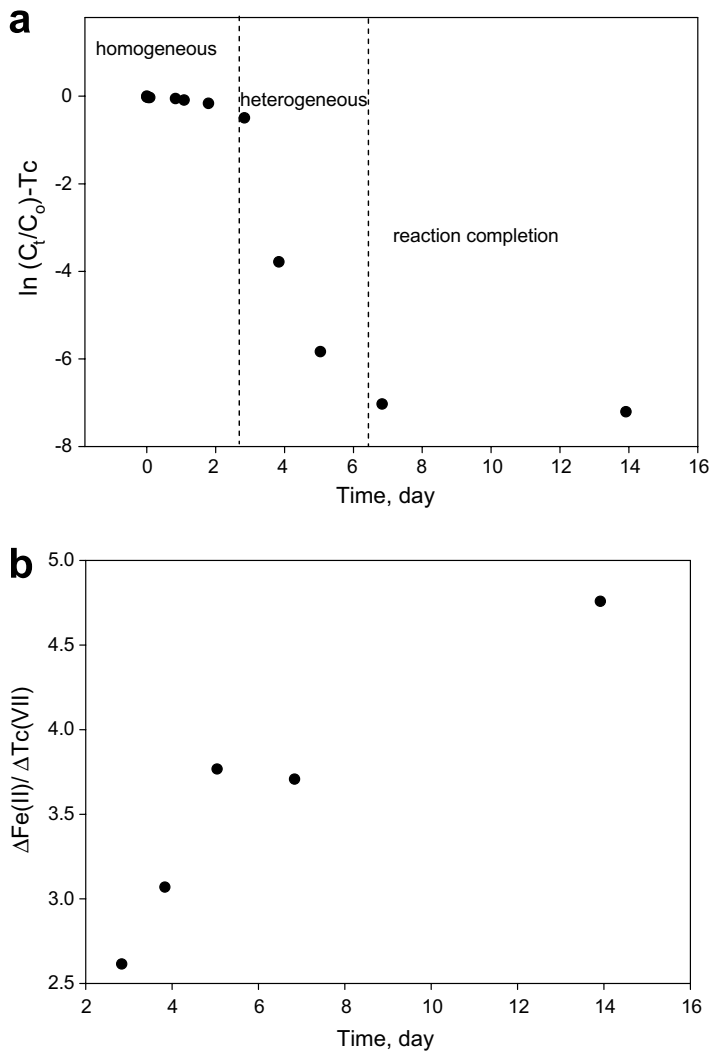

Fig. 4. (a) Pseudo-first order reaction plot for the reduction of $11 \mu \mathrm{mol} / \mathrm{L} \mathrm{Tc}(\mathrm{VII})$, by $0.20 \mathrm{mmol} / \mathrm{L} \mathrm{Fe}(\mathrm{II})$ at $\mathrm{pH} 7$ (Reactor 5). Three reaction regions were evident as noted. The breakpoint between homogeneous and heterogeneous reduction intersected the $y$-axis (e.g., $t=0$ ) at higher $\mathrm{Fe}(\mathrm{II})$ and $\mathrm{pH}$ values. (b) Apparent stoichiometry for the $\mathrm{Tc}(\mathrm{VII})-\mathrm{Fe}(\mathrm{II})$ redox reaction in Reactor 5 as inferred by wet chemical analyses of the aqueous phase. Uncertainty in the ferrozine procedure and small changes in $[\mathrm{Fe}(\mathrm{II})]_{\mathrm{aq}}$ prevented stoichiometry calculations for time points before day 2 .

homogeneous and heterogeneous regions, when observed, consistently occurred after $0.010-0.015 \mathrm{mmol} / \mathrm{L}$ of $\mathrm{Fe}(\mathrm{II})$ had been oxidized by $\mathrm{Tc}(\mathrm{VII})$ reduction. Plots of $\ln \left[C_{t} /\right.$ $C_{\mathrm{o}}$ ] versus time for the homogeneous region data were slightly to markedly curvilinear, indicating lack of overall conformance to pseudo-first order behavior. An exception

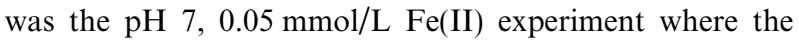
homogeneous region was linear $\left(r^{2}=0.869\right)$ yielding $k_{1}=0.005( \pm 0.0005) \mathrm{day}^{-1}$.

The stoichiometry of the redox reaction was difficult to asses for the homogeneous region because the small changes in $\mathrm{Fe}(\mathrm{II})$ concentration were within the variance of the ferrozine-Fe(II) analytical procedure. Reaction stoichiometry as determined by aqueous phase $\mathrm{Tc}(\mathrm{VII})$ and $\mathrm{Fe}(\mathrm{II})$ analyses was analytically accessible during the heterogeneous phase because of greater reaction progress (Shown for Reactor 5 in Fig. 4b). Consistent with Reaction 3 , an approximate $3: 1 \mathrm{Fe}(\mathrm{II}) / \mathrm{Tc}(\mathrm{VII})$ loss ratio was observed for all experiments at the early stages of heterogeneous reduction. This ratio increased to over 4 following reaction completion as $\mathrm{Fe}(\mathrm{II})$ sorbed to and reacted with solid-phase products of the redox reaction.

\subsection{Characterization of the reduced Fe/Tc product}

The results of the wet chemical experiments indicated that the $\mathrm{Fe}(\mathrm{II})_{\mathrm{aq}}-\mathrm{Tc}(\mathrm{VII})$ solute mixtures were free of trace contaminant oxygen and that the changes in the aqueous concentration of the two solutes were a consequence of the direct electron transfer reaction between them. The redox reaction yielded a solid-phase product containing insoluble Fe and Tc(IV). The electron stoichiometry of the redox reaction [Eq. (3)] implied that the precipitates would exhibit a Fe:Tc ratio of 3, but higher ratios were observed (Table 2, Fig. 4b). The precipitate was ferrimagnetic (at least in part) as it was collected by stir bars in the reaction vessels indicating the presence of magnetite or maghemite. The solids were dark-brown to black in color. Significant efforts were expended to characterize the solid phase reaction products in order to more accurately define the overall redox reaction defined conceptually by Eq. (3).

\subsubsection{Transmission electron microscopy}

Precipitates obtained from reaction vessels at $\mathrm{pH} 6.8$, 7.0, and 8.0 were analyzed by transmission electron microscopy. Solids from multiple experiments were analyzed at $\mathrm{pH} 7.0$ and 8.0 to assess potential variations in product character between replicated experiments, and none were observed. The precipitates from $\mathrm{pH} 7.0$ and $\mathrm{pH} 8.0$ were virtually identical in all respects. They consisted of loosely connected, 30-50 nm particle aggregates arranged in chain or "sponge-like" morphology (Fig. 5). The individual aggregates were themselves comprised of tightly packed 5-10 nm crystallites (Fig. 5b) that exhibited distinct lattice fringes (Fig. 5c). Precipitates obtained from the $\mathrm{pH} 6.8$ experiment exhibited different morphology from those at higher $\mathrm{pH}$. Approximately $63 \%$ of the precipitate mass existed in the form of $50 \mathrm{~nm}$ aggregates comprised of tightly packed, $<3 \mathrm{~nm}$ particles (Fig. 6a). The remainder $(\sim 37 \%)$ was present in the form of more crystalline, somatoidal structures up to $50 \mathrm{~nm}$ long (Fig. 6b), that exhibited distinct lattice fringes (Fig. 6c). These structures were similar to nascent hematite formed from ferrihydrite (Fischer and Schwertmann, 1974).

SAED patterns were measured on over thirty locations in the $\mathrm{pH} 6.8,7$, and 8 samples. These ranged from common diffuse patterns characteristic of poorly crystalline materials ( $\sim 75 \%$ of the patterns), to less common distinct diffraction banding indicative of crystalline materials ( $\sim 25 \%$ of the patterns). The patterns collected for the more crystalline material were virtually identical for all three $\mathrm{pH}$ samples indicating the presence of a common, single phase. In the most well-defined of these patterns (Fig. 7a and b), six d-spacings were observed: $0.245,0.215,0.164,0.144$, 0.126 , and $0.120 \mathrm{~nm}$. These spacings well matched rings calculated from the reference powder diffraction file of magnetite (PDF file 19-0629) and overlain on Fig. 7a, specifically corresponding to d-spacings at $0.253-0.242,0.210,0.162$, $0.142,0.128-0.127$, and $0.121 \mathrm{~nm}$. Diffraction patterns for 6-line ferrihydrite (PDF file 29-0712; Fig. 7b) did not show agreement with the sample data, except at the largest d-spacings. Similar comparisons were made between many other Fe oxides (hematite, goethite, akaganeite, maghemite, 
a

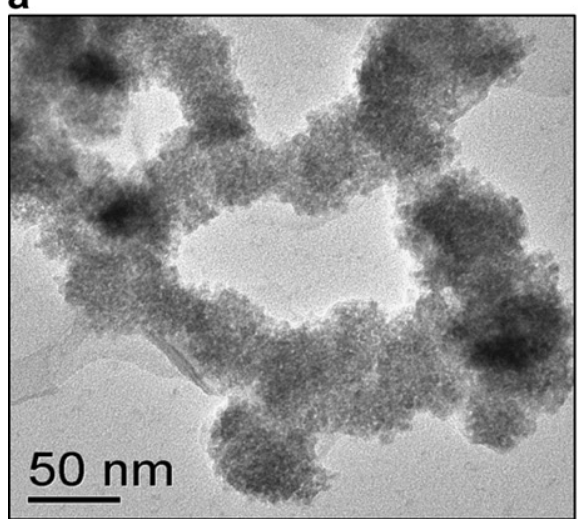

b

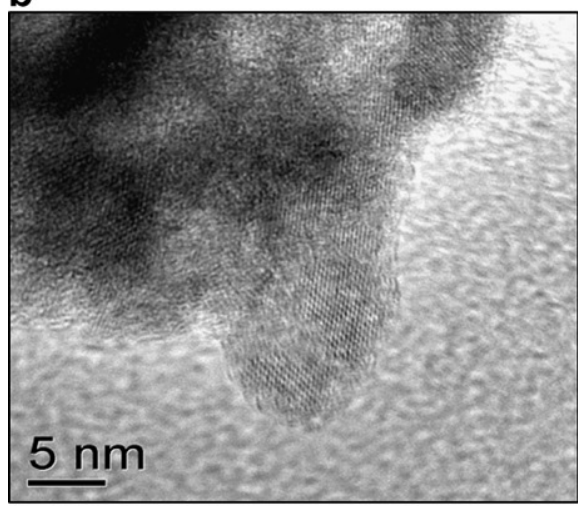

C

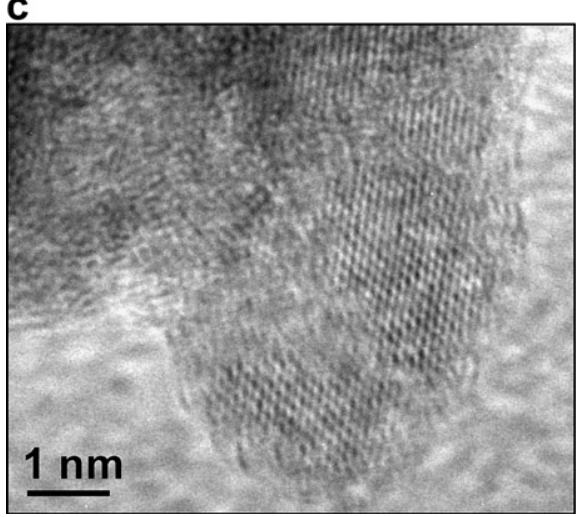

Fig. 5. Transmission electron micrographs of the $\mathrm{pH} 7.0, \mathrm{Fe} / \mathrm{Tc}$ precipitate at increasingly small scale.

titanomagnetites) and Tc compounds, with only synthetic feroxyhite (PDF file 13-0087) and maghemite (PDF file 25-1402) providing partial matches to the observed rings that were inferior to that observed for magnetite.

The chemical compositions of the precipitates were mapped by EDS at different spatial scales ranging from $>100 \mathrm{~nm}$ to $<5 \mathrm{~nm}$. The Fe:Tc atomic ratio was found to be the same at all spatial scales in the $\mathrm{pH} 7$ and 8 samples, indicating a chemically homogeneous precipitate without distinct areas of Tc localization. Analyses around crystallite peripheries showed no evidence for the concentration of $\mathrm{Tc}$ on mineral surfaces, with Fe:Tc atomic ratios identical to the bulk. Slight variations in composition were observed a

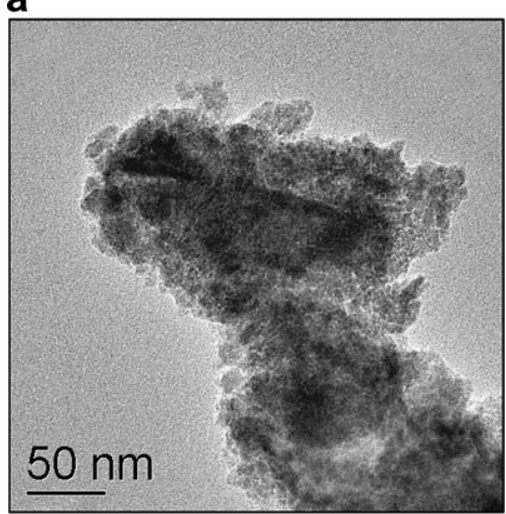

b

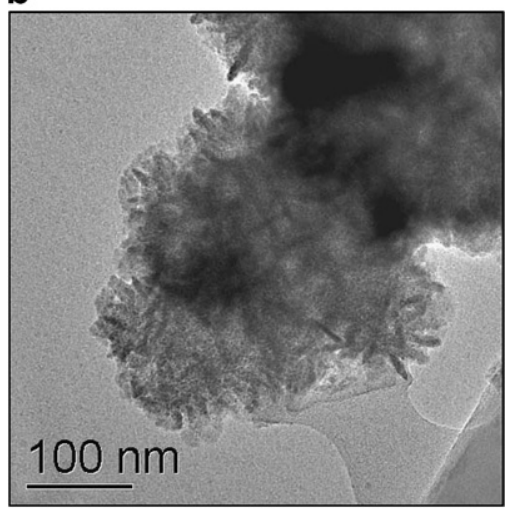

C

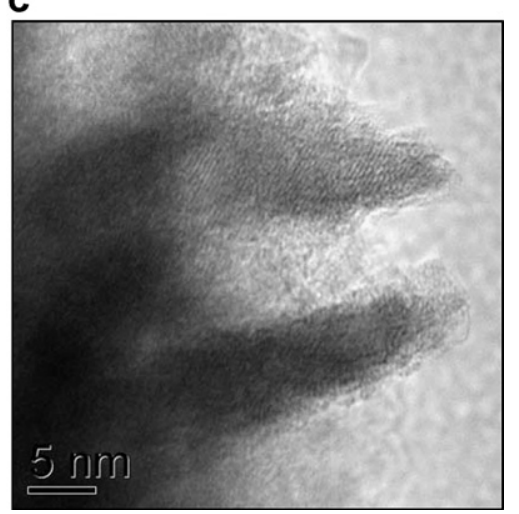

Fig. 6. Transmission electron micrographs of the $\mathrm{pH} 6.8, \mathrm{Fe} / \mathrm{Tc}$ precipitates: (a) tightly packed $<3 \mathrm{~nm}$ particles, (b) larger "somatoid-like" crystallites, and (c) detail of somatoids.

in spot analyses at $<10 \mathrm{~nm}$, but all analyses yielded average Fe:Tc composition values of $86( \pm 0.5): 14( \pm 0.5)$ atomic $\%$. The pH 6.8 samples were also homogeneous at different spatial scales, although spot analyses at the $5 \mathrm{~nm}$ scale showed a slight difference in Fe:Tc composition between the fine grained aggregates $(86.1 \%: 13.9 \%)$ and the somatoidal precipitates $(85.0 \%: 15.0 \%), n=6$ for each. This difference was consistent between measurements, but was near the limit of precision for EDS data reduction, and so may not be significant. The compositional results were consistent with those from wet chemical analyses (Table 2). 
a

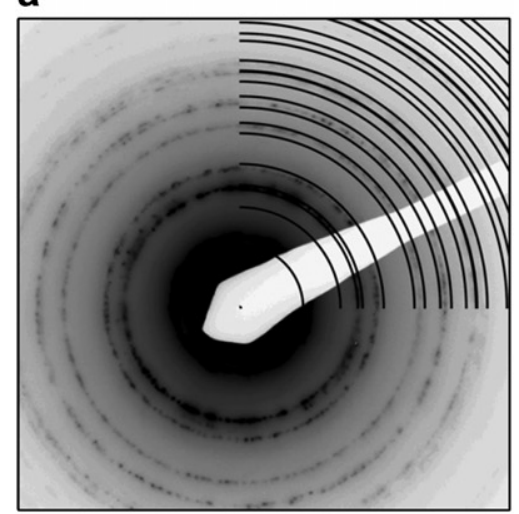

b

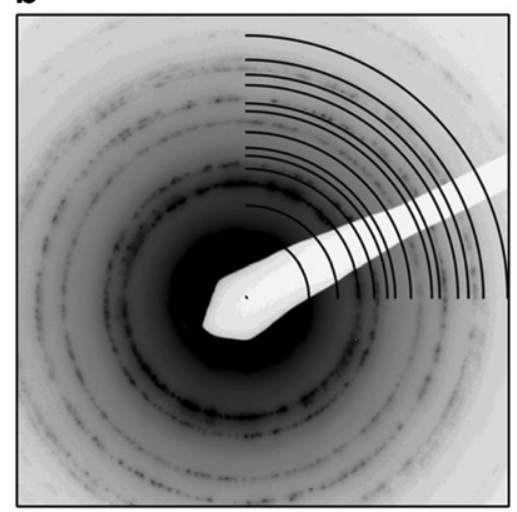

c

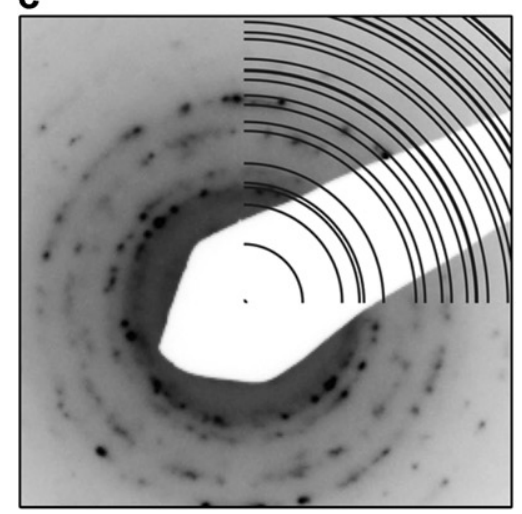

Fig. 7. Selected area electron diffraction (SAED) of (a) $\mathrm{pH} 8 \mathrm{Fe} / \mathrm{Tc}$ precipitate with calculated diffraction rings of magnetite (PDF \#190629), (b) same sample pattern, but with computed lines of ferrihydrite (PDF \#29-0712), and (c) oxidized $\mathrm{pH} 8 \mathrm{Fe} / \mathrm{Tc}$ precipitate with computed lines of magnetite (PDF \#19-0629).

\subsubsection{XANES and EXAFS spectroscopy}

XANES analyses revealed that the average Fe valence for the Fe/Tc samples was below that of Fe(III) (Fig. 8a). Using $\mathrm{FeO}$ and hematite as standards, average valences of $2.85[15 \% \mathrm{Fe}(\mathrm{II})]$ for the $\mathrm{pH} 7$ and $2.75[25 \% \mathrm{Fe}(\mathrm{II})]$ for the $\mathrm{pH} 8 \mathrm{Fe} / \mathrm{Tc}$ precipitates were determined from linear combination fits of the edge region. A similar analysis for magnetite yielded an average valence of 2.63 [37\% Fe(II)] that was close to, but slightly lower than the expected value of $2.67[33 \% \mathrm{Fe}(\mathrm{II})]$. The Fe valence measurements suggested that significant residual $\mathrm{Fe}(\mathrm{II})_{\mathrm{aq}}$ in the wet chemical experiments adsorbed to and reacted with the initial $\mathrm{Fe}(\mathrm{III}) / \mathrm{Tc}(\mathrm{IV})$ product of the redox reaction to yield a mixed valence $\mathrm{Fe}(\mathrm{III})-\mathrm{Fe}(\mathrm{II}) / \mathrm{Tc}$ precipitate.

Both magnetite and maghemite $\left(\gamma-\mathrm{Fe}_{2} \mathrm{O}_{3}\right)$ have a combination of tetrahedral and octahedral $\mathrm{Fe}$ sites, while only octahedral sites exist in ferrihydrite $\left(5 \mathrm{Fe}_{2} \mathrm{O}_{3} \cdot 9 \mathrm{H}_{2} \mathrm{O}\right)$ and hematite $\left(\alpha-\mathrm{Fe}_{2} \mathrm{O}_{3}\right)$. These differences in coordination environment affect the small pre-edge feature at $7113 \mathrm{eV}$ (Fig. 8a). For symmetric octahedral bonding as found in ferrihydrite (primarily) and hematite the feature is strongly suppressed. Debate has persisted on the presence of tetrahedral $\mathrm{Fe}(\mathrm{III})$ in ferrihydrite (Eggleston and Fitzpatrick, 1988; Zhao et al., 1994) which exhibits a small pre-edge feature. For magnetite, a phase whose presence was implied in the $\mathrm{Fe} / \mathrm{Tc}$ precipitates by SAED (Fig. 7a), the feature is stronger due to the tetrahedral sites and distortion in the octahedral sites. An increase in the pre-edge feature above that observed for ferrihydrite and consistent with the presence of magnetite/maghemite was noted for the two $\mathrm{Fe} / \mathrm{Tc}$ precipitates (Fig. 8a), suggesting the possibility of some tetrahedral $\mathrm{Fe}$ bonding in the redox products.

The extended fine structure for $\mathrm{Fe}$ in the $\mathrm{Fe} / \mathrm{Tc}$ precipitates $[\chi(k)$ data in Fig. 9a] bore strong similarity to our standard of 6-line ferrihydrite, with the suggestion of a contribution from stoichiometric magnetite especially in the $\mathrm{pH} 8$ sample. The average Fe environment for the magnetite and maghemite structures is quite similar, and as a consequence it was not possible in our EXAFS data analyses to discern preference for either structure. Because of evidence for the presence of magnetite in the $\mathrm{Fe} / \mathrm{Tc}$ precipitates from SAED (Section 3.3.1), we presumed that magnetite was the primary source of tetrahedral Fe bonding in the samples. The $\chi(\mathrm{k})$ data were consequently fitted to linear combinations of ferrihydrite and magnetite. The EXAFS spectra of the $\mathrm{pH} 8$ sample was well fitted with $11 \%$ magnetite and $89 \%$ ferrihydrite (Fig. 9b). Similar fitting for the $\mathrm{pH}$ 7 sample yielded $100 \%$ ferrihydrite, with the suggestion of the presence of a small amount of an additional non-magnetite component (data not shown).

The near edge Fe spectra for $\mathrm{Fe} / \mathrm{Tc}$ samples were fitted using a similar linear combination approach. In this fitting, it was assumed that magnetite was the sole contributor of $\mathrm{Fe}(\mathrm{II})$ to the near edge spectrum. Modeling of the sample near edges (Fig. 8b) yielded significantly higher magnetite contents then obtained from EXAFS: $62 \%$ magnetite/38\% ferrihydrite for the $\mathrm{pH} 8$ sample (Fig. $8 \mathrm{~b}$ ), and 25\% magnetite $/ 75 \%$ ferrihydrite for the $\mathrm{pH} 7$ sample (data not shown). Accepting the results of the EXAFS fitting as a reasonable phase and structural model of the samples, the contrasting results of the XANES fitting implied that the ferrihydrite contained significant Fe(II). Using the EXAFS fitted phase distributions as a constraint, we computed $\mathrm{Fe}(\mathrm{II})$ contents of $20.6 \%$ and $15 \%$ in the ferrihydrite of the $\mathrm{pH} 8$ and $\mathrm{pH}$ 7 samples, respectively.

The Tc near edge spectrum for both of the Fe/Tc precipitates was virtually identical to nanometer-sized, poorly crystalline $\mathrm{TcO}_{2} \cdot n \mathrm{H}_{2} \mathrm{O}$, indicating $\mathrm{Tc}(\mathrm{IV})$ valence (data not shown). The absence of Tc(VII), which forms rapidly in presence of oxygen, indicated success in our sample 

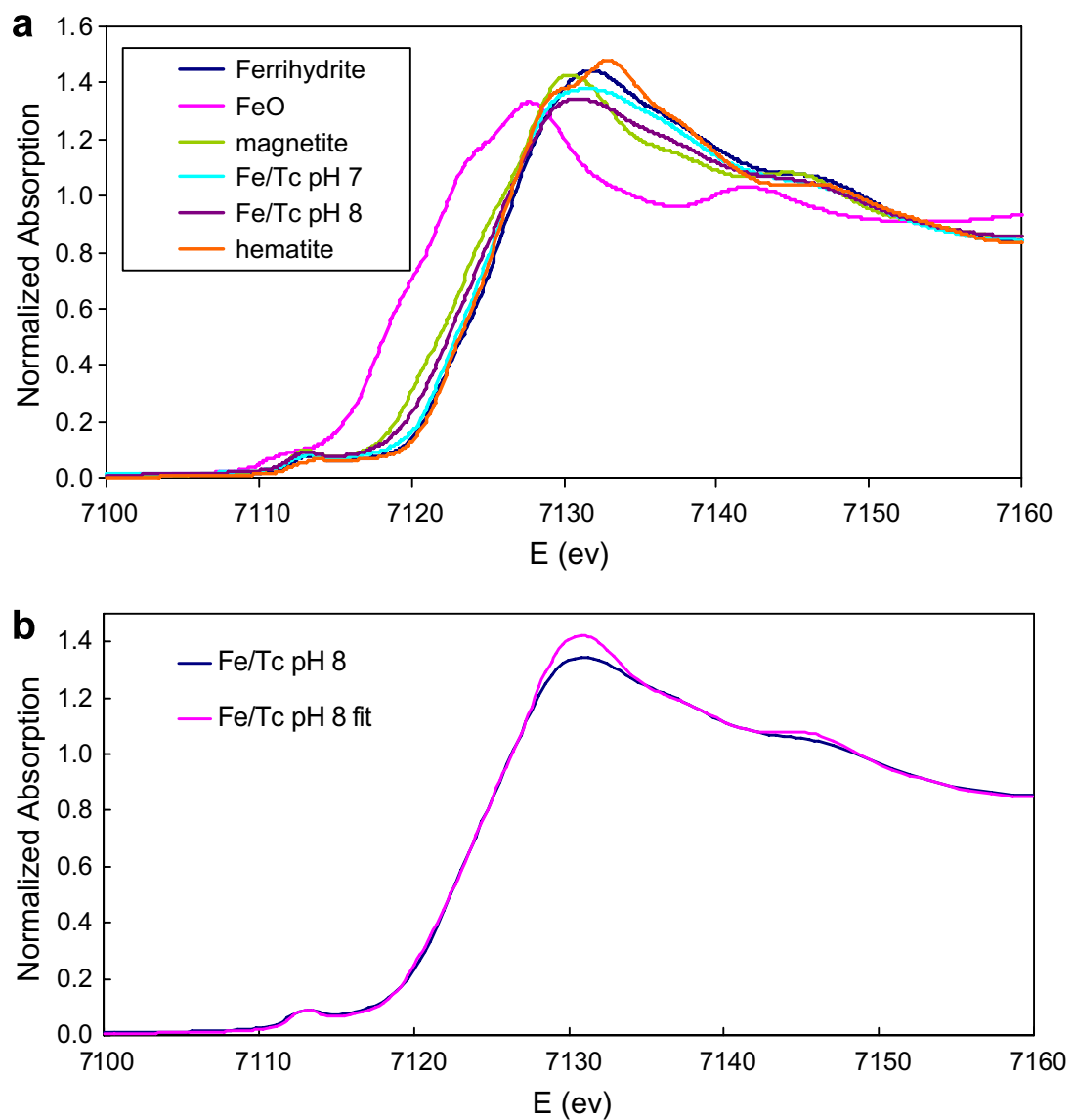

Fig. 8. (a) $\mathrm{Fe}-\mathrm{XANES}$ spectra of the $\mathrm{pH} 7$ and $\mathrm{pH} 8 \mathrm{Fe} / \mathrm{Tc}$ precipitates as compared to ferrous oxide [Fe(II)O], magnetite [ $\left.\mathrm{Fe}(\mathrm{II}) \mathrm{Fe}(\mathrm{IIII})_{2} \mathrm{O}_{4}\right]$, hematite $\left[\alpha-\mathrm{Fe}(\mathrm{III})_{2} \mathrm{O}_{3}\right]$, and ferrihydrite $\left[5 \mathrm{Fe}(\mathrm{III})_{2} \mathrm{O}_{3} \cdot 9 \mathrm{H}_{2} \mathrm{O}\right]$, and (b) results of linear combination fitting of the $\mathrm{pH} 8$ sample data with $62 \%$ magnetite and $38 \%$ ferrihydrite.

preservation efforts. The Tc-EXAFS data were quite similar for the redox products at both pHs (Fig. 10a). These, in turn, were significantly different from that of $\mathrm{TcO}_{2} \cdot n \mathrm{H}_{2} \mathrm{O}$, but were virtually identical to our reference sample of $\mathrm{Tc}$ (IV) that was coprecipitated with ferrihydrite (Fig. 10a).

A number of models were applied to the EXAFS data to determine the Tc(IV) coordination environment. The first shell was well fit with 6 oxygen neighbors, regardless of model. The outer shell distances, however, were inconsistent with the extended edge sharing, Tc(IV)-octahedral chain model as described by Lukens et al. (2002) and recently applied to $\mathrm{Tc}(\mathrm{VII})$ reaction products with environmental reductants (Maes et al., 2004), as the second shell transform peak was strongly suppressed from that expected for multiple Tc second-shell neighbors. The extended distances also did not agree with Tc(IV) substitution in magnetite-like octahedral sites.

Because of the close similarity of the $\mathrm{pH} 7$ and 8 EXAFS data with the Tc(IV)-ferrihydrite precipitate, and the dominance of ferrihydrite in the precipitate as implied by FeEXAFS fitting (e.g., Fig. 9b), we evaluated whether the Tc-EXAFS spectrum was consistent with Tc(IV) adsorption to, or substitution within ferrihydrite. This evaluation began with the development of a ferrihydrite structural model to describe the Fe-EXAFS spectrum of the 6-line fer- rihydrite standard (Fig. 9a). A conceptual ferrihydrite structural model to guide these calculations was abstracted from Drits et al. (1993), Janney et al. (2000a,b), Jansen et al. (2002). This model contained numerous different Fe sites (up to 12) because of the defected and disordered ferrihydrite structure. FEFF calculations on these sites indicated that they exhibited some similar characteristics: (i) a split first shell, (ii) two or more separate second shell Fe neighbors, and (iii) a range of third shell $\mathrm{O}$ neighbors. Under the assumption that Fe site occupancy in ferrihydrite averaged 0.5 , the following structural model was abstracted from the conceptual model and used to fit the ferrihydrite Fe-EXAFS data: 3 short and 3 long $O$ first shell bonds, 3 short and 3 long $\mathrm{Fe}$ second shell bonds, and 3 short and 3 long $\mathrm{O}$ third shell bonds. This structural, two Fe-shell model gave good fit to the ferrihydrite Fe-EXAFS data (Fig. 9c) with reasonable coordination numbers, bond distances, and fit statistics (Table 3). The model was therefore considered a reasonable, but not unique representation of the structural environment of $\mathrm{Fe}$ in ferrihydrite.

The Tc-EXAFS data could also be explained within context of the ferrihydrite model. Our first modeling attempt embedded a symmetric $\mathrm{TcO}_{6}$ octahedron $(\mathrm{Tc}-\mathrm{O}=2.00 \AA$ ) in the defected ferrihydrite structure in a bidentate, edgesharing configuration with an octahedral $\mathrm{FeO}_{6}$ site. A key 

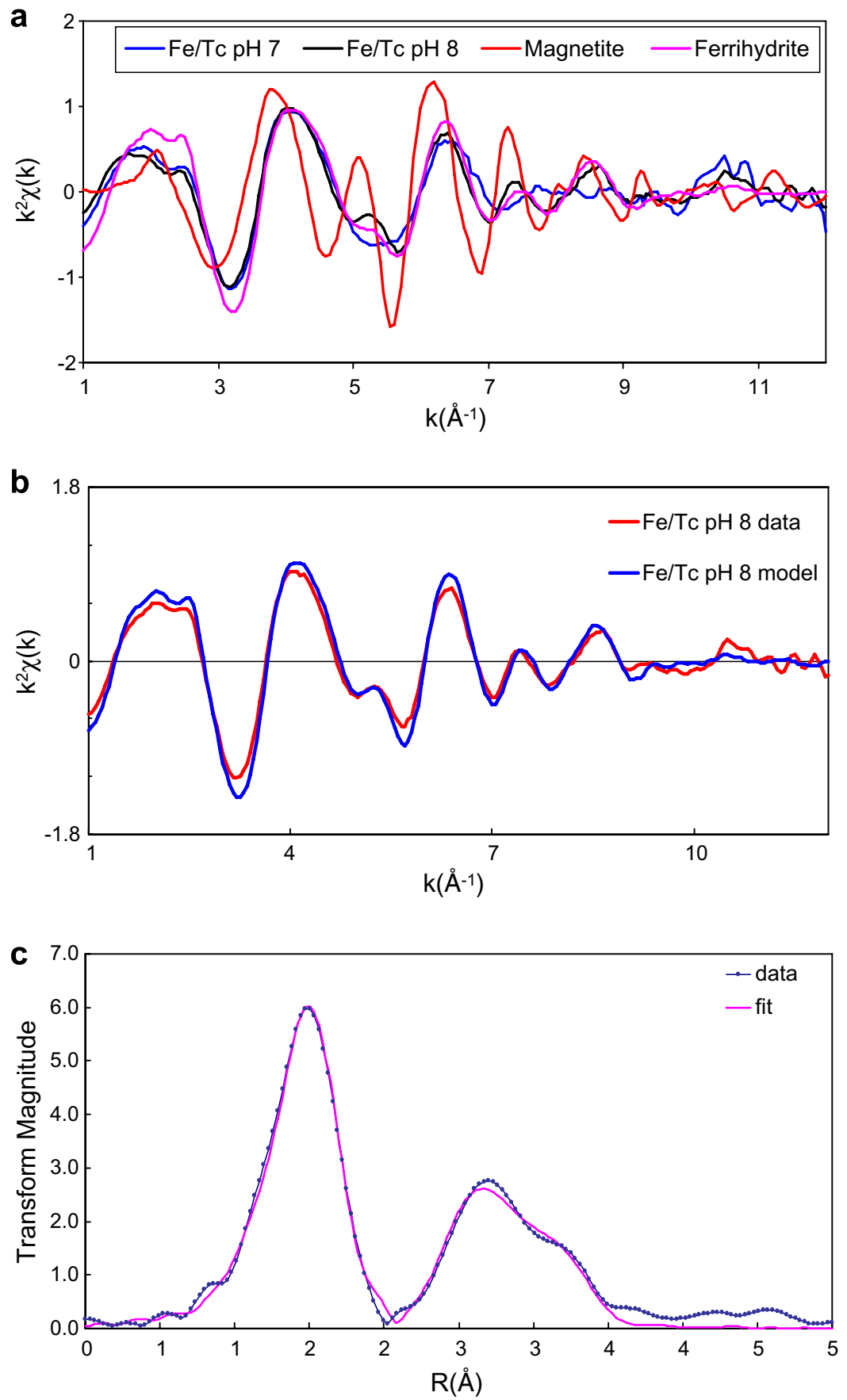

Fig. 9. (a) Fe-EXAFS $[\chi(k)$ data] of the $\mathrm{pH} 7$ and $\mathrm{pH} 8 \mathrm{Fe} / \mathrm{Tc}$ precipitates as compared to magnetite and 6-line ferrihydrite, (b) linear combination modelling of the $\mathrm{pH} 8 \chi(k)$ data using $11 \%$ magnetite and $89 \%$ ferrihydrite, and (c) radial transform of the Fe-EXAFS spectrum of 6-line ferrihydrite and results of fitting with the 2-Fe shell model.

feature of this model was a short Tc-Fe second shell bond similar to the short Tc-Tc bond in the amorphous $\mathrm{TcO}_{2} \cdot n \mathrm{H}_{2} \mathrm{O}$ described by Lukens et al. (2002).

Application of this model to the $\mathrm{pH} 7$ and $\mathrm{pH} 8$ sample data produced fits that looked reasonable, but upon closer inspection there were problems. The Tc-Fe disorder was unreasonably large and the fit to the second transform peak was not ideal, especially in terms of phase. The model was consequently extended to allow for the formation of $\mathrm{TcO}_{2}$ polymers (Vichot et al., 2002). These polymers could then coordinate to the ferrihydrite surface or vacancy sites. The main difference in this second model was a reduced contribution from $\mathrm{Tc}-\mathrm{Fe}$ bonds, and the addition of Tc-Tc bonds. This alternative model was deemed plausible given the high Tc concentration in the precipitates.

In practice, it was found that fitting the second model was problematic since the EXAFS contribution from $\mathrm{Tc}-\mathrm{Fe}$ and $\mathrm{Tc}-\mathrm{Tc}$ were out of phase and nearly cancelled. 


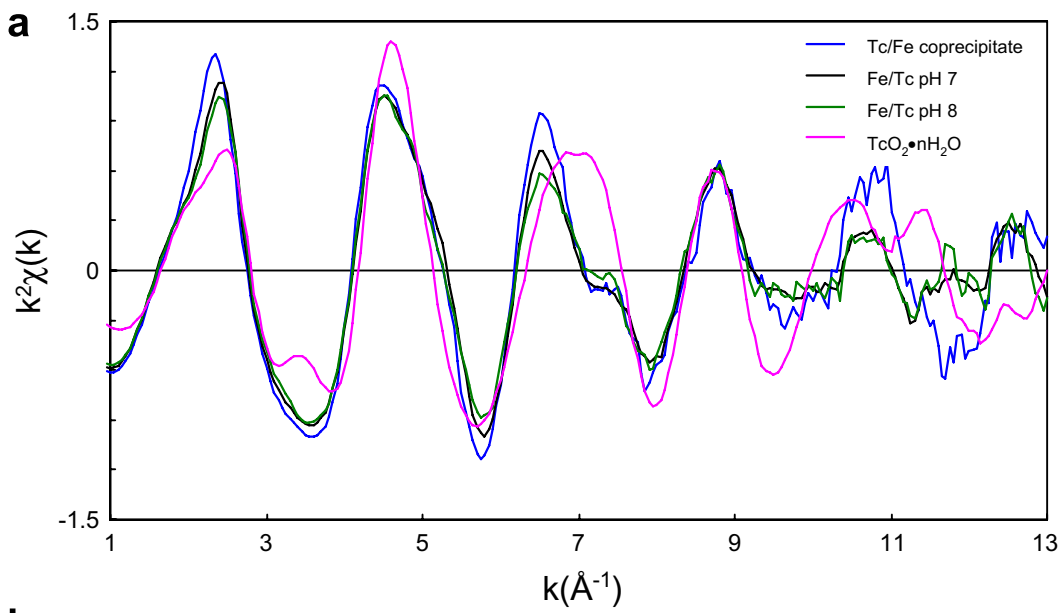

b
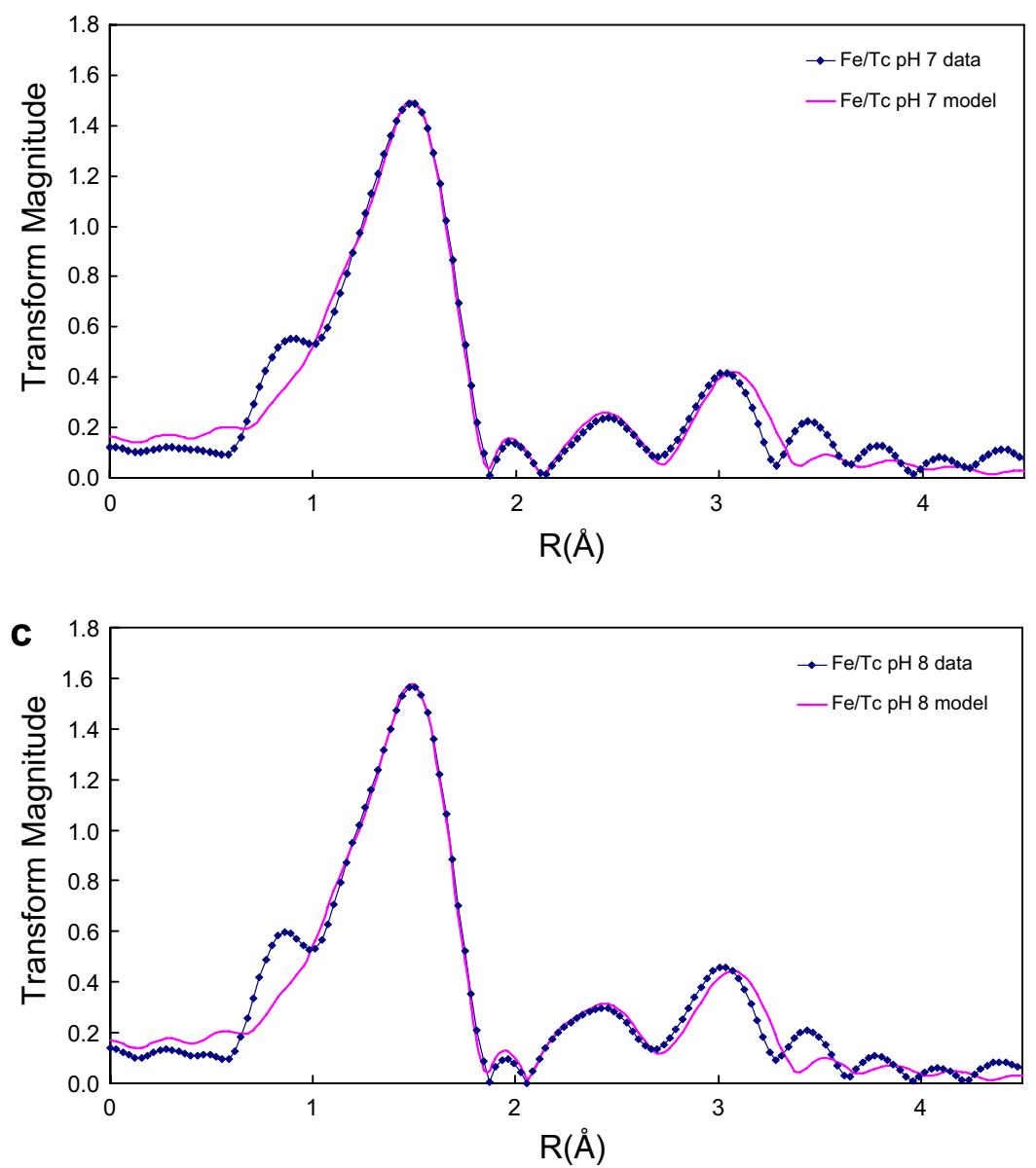

Fig. 10. (a) Tc-EXAFS $\left[\chi(\mathrm{k})\right.$ data] of the $\mathrm{pH} 7$ and $\mathrm{pH} 8 \mathrm{Fe} / \mathrm{Tc}$ precipitates as compared to $\mathrm{TcO}_{2} \cdot n \mathrm{H}_{2} \mathrm{O}$ and Tc(IV)-coprecipitated with ferrihydrite, and (b) Fourier transform of the $\mathrm{Fe} / \mathrm{Tc} \mathrm{pH} 7$ data and fitting results with the dimer model. (c) Fourier transform of the Fe/Tc $\mathrm{pH}$ 8 data and fitting results with the dimer model.

To constrain the fits, the Tc-Tc bond parameters were fixed at the values reported for the $\mathrm{TcO}_{2} \cdot n \mathrm{H}_{2} \mathrm{O}$ solid (Lukens et al., 2002), and the number of Tc-Tc and Tc-Fe bonds were determined by the length of the Tc-Tc chains. For example, if the Tc chain length was two, each Tc on average would have one Tc neighbor, and 0.5 Fe neighbors.
The constrained polymer model produced good fits for the $\mathrm{pH} 7$ and $\mathrm{pH} 8$ samples (Fig. 10b and c) using reasonable parameters (Table 4). The model included an octahedral first shell, short Tc and Fe contributions constrained as discussed above, axial $\mathrm{O}$ neighbors from neighboring $\mathrm{Fe}$ and Tc octahedron, and a longer Fe bond. The multiple 
Table 3

Ferrihydrite structural model derived from Fe-EXAFS fitting of 6-line ferrihydrite

\begin{tabular}{llll}
\hline Shell & $N$ (fixed) & $R(\AA)$ & $\sigma^{2}\left(\AA^{2}\right)$ \\
\hline 1st O short & 3 & 1.92 & 0.0056 \\
1st O long & 3 & 2.06 & 0.0089 \\
Fe short & 3 & 2.99 & 0.0138 \\
Fe long & 3 & 3.45 & 0.0110 \\
2nd O short & 3 & 3.52 & $0.0099^{\mathrm{a}}$ \\
2nd O long & 3 & 3.71 & $0.0099^{\mathrm{a}}$ \\
\hline
\end{tabular}

The fitting range was $2-13 \AA^{-1}$ in k-space and $1-3.5 \AA$ in r-space giving 17 possible independent parameters with 12 fitting parameters used in the model.

${ }^{a}$ Constrained to be equal.

Table 4

Results of fitting the Tc(IV) dimer model to the $\mathrm{pH} 7$ and $\mathrm{pH} 8$ Tc-EXAFS data

\begin{tabular}{llll}
\hline Shell & $N$ & $R(\AA)$ & $\sigma^{2}\left(\AA^{2}\right)$ \\
\hline$T c / F e p H 8$ & & & \\
1st O & $6^{*}$ & $2.01(0.01)$ & $0.0065(0.001)$ \\
Fe short & $0.5(0.1)$ & $2.57(0.02)$ & $0.0014(0.002)$ \\
Tc & $1.0(0.2)$ & $2.57^{*}$ & $0.007^{*}$ \\
2nd O short & $2^{*}$ & $3.04(0.04)$ & $0.0034(0.002)$ \\
Fe long & $2^{*}$ & $3.50(0.03)$ & $0.0032(0.002)$ \\
TclFe pH 7 & & & \\
1st O & $6^{*}$ & $2.01(0.01)$ & $0.0065(0.001)$ \\
Fe short & $0.3(0.1)$ & $2.58(0.02)$ & $0.0008(0.002)$ \\
Tc & $1.3(0.3)$ & $2.57^{*}$ & $0.007^{*}$ \\
2nd O short & $2^{*}$ & $3.06(0.04)$ & $0.0082(0.002)$ \\
Fe long & $2^{*}$ & $3.50(0.03)$ & $0.0038(0.002)$ \\
\hline Paramers & &
\end{tabular}

Parameters noted by ${ }^{*}$ were fixed in the data fitting.

scattering parameters for paths within the Tc-O octahedron were determined from the corresponding single scattering paths and were not free parameters. The longer $\mathrm{Fe}$ bond was added to account for the extended Fe neighbors observed in the ferrihydrite structural model (Fig. 9c; Table 3 ) that influence the third Tc transform peak. Typically, the data range allowed for about 15 fitting parameters, but only 11 parameters were generally fit due to the imposed structural constraints. These fits were significantly better than with the single $\mathrm{TcO}_{6}$ octahedron model, and, on average, indicated that the Tc polymers were approximately dimers (e.g., $\mathrm{N}_{\mathrm{Tc}} \sim 1$; Table 4).

\subsubsection{Mössbauer spectroscopy}

The wet chemical experiments (Figs. 2 and 3) were performed with isotopically enriched $\mathrm{Fe}(\mathrm{II})$ containing $96.7 \%$ ${ }^{57} \mathrm{Fe}$, the Mössbauer active $\mathrm{Fe}$ isotope. This isotopic enrichment allowed Mössbauer measurements on the Fe/Tc precipitates in spite of their very low mass yield (e.g., $<10 \mathrm{mg}$ ). Mössbauer measurements were performed on the precipitates from the $\mathrm{pH} 6.8,7.0$, and 8.0 experiments at 298,77 , and $12 \mathrm{~K}$. The lowest temperature measurements did not yield essential information and are not reported here. The Mössbauer spectra of all three samples exhibited common aspects and only those from $\mathrm{pH} 7$ and 8 are presented herein.
The room temperature spectra (RT, 298) of both samples were dominated by a doublet at $0-1.5 \mathrm{~mm} / \mathrm{s}$ (Figs. 11 and 12a). The apparent Mössbauer parameters of the doublets were isomer shift $(\delta)=0.4 \mathrm{~mm} / \mathrm{s}$ and quadrupole splitting $(\Delta)=0.6 \mathrm{~mm} / \mathrm{s}$. Doublets of this nature have been reported for ferrihydrite (Rancourt et al., 2005), superparamagnetic/nm-sized goethite (Murad and Cashion, 2004), magnetite (Goya et al., 2003), and maghemite (da Costa et al., 1998). The $\mathrm{pH} 8$ sample also displayed two sextets in its RT spectrum (Fig. 11a; marked with $t$ and $o$ ). The outer sextet $(t)$ was due to $\mathrm{Fe}(\mathrm{III})$ in a tetrahedral coordination environment $[\delta=0.32 \mathrm{~mm} / \mathrm{s}$ and quadrupole shift parameter $(\varepsilon)=-0.15 \mathrm{~mm} / \mathrm{s}$, and hyperfine field $\left(B_{\mathrm{hf}}\right)=47.5$ Tesla $\left.(\mathrm{T})\right]$. The inner sextet was consistent with a mixture of $\mathrm{Fe}(\mathrm{II})$ and $\mathrm{Fe}(\mathrm{III})$ in octahedral coordination $\left(\delta=0.73 \mathrm{~mm} / \mathrm{s}\right.$ and $\varepsilon=-0.06 \mathrm{~mm} / \mathrm{s}$, and $\left.B_{\mathrm{hf}}=43.5 \mathrm{~T}\right)$. Consistent with SAED (Fig. 7a) and EXAFS fitting (Fig. 9b), this sextet pair indicated that a magnetite-like phase was present, although the observed $B_{\mathrm{hf}}$ for the tetrahedral $(47.5 \mathrm{~T})$ and octahedral $(43.5 \mathrm{~T})$ sites were slightly lower than pure magnetite $[t \sim 49 \mathrm{~T}, o \sim 46 \mathrm{~T}$; (Murad and Schwertmann, 1993)]. Moreover, the presence of discernable sextets for octahedral and tetrahedral sites at RT implied that the magnetite responsible for this spectral response was nominally $>50 \mathrm{~nm}$ in size (Goya et al., 2003), although crystallites of this size were not noted by TEM. The RT spectral character and Mössbauer parameters for the $\mathrm{pH} 8$ precipitate were similar to those observed for mineral products resulting from the reaction of $\mathrm{Fe}^{2+}{ }_{(\mathrm{aq})}$ with

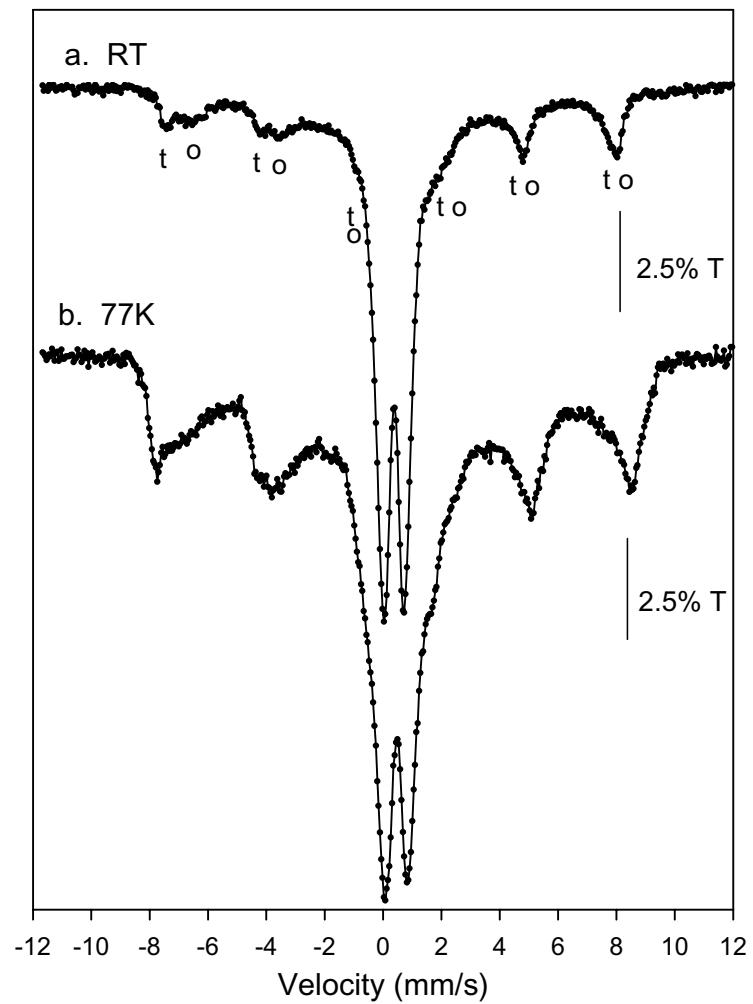

Fig. 11. ${ }^{57} \mathrm{Fe}$ transmission Mössbauer spectra of the $\mathrm{pH} 8, \mathrm{Fe} / \mathrm{Tc}$ precipitates: (a) room temperature (RT) and, (b) $77 \mathrm{~K}$. 


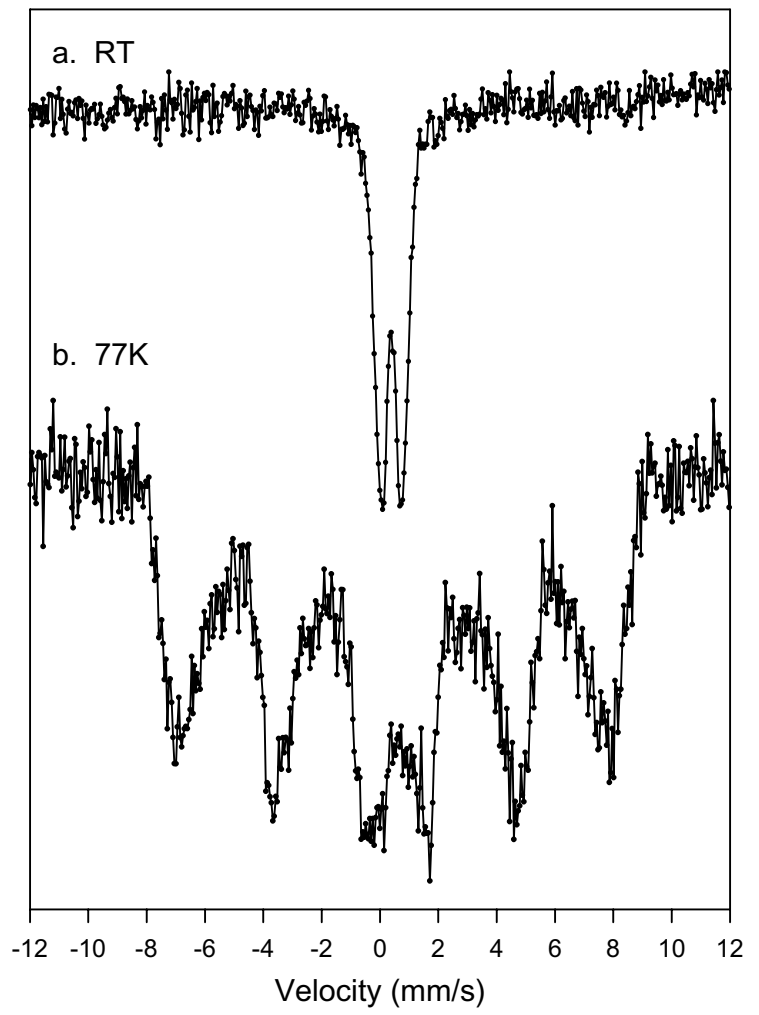

Fig. 12. ${ }^{57} \mathrm{Fe}$ transmission Mössbauer spectra of the $\mathrm{pH} 7, \mathrm{Fe} / \mathrm{Tc}$ precipitates: (a) room temperature (RT), and (b) $77 \mathrm{~K}$.

ferrihydrite at alkaline $\mathrm{pH}$ with $\mathrm{Fe}(\mathrm{II}) / \mathrm{Fe}(\mathrm{III})=0.15$ (Jolivet et al., 1992).

Lowering the measurement temperature to $77 \mathrm{~K}$ reduced the spectral area of the central doublet in both samples (Fig. 11 and 12b). The doublet was completely eliminated at $\mathrm{pH} 7$, where the precipitate displayed a magnetically ordered, partially collapsed sextet (Fig. 12b), consistent with the presence of a single phase. Recorded blocking temperatures (where $50 \%$ of the phase is magnetically ordered) for ferrihydrite, in contrast, range from 54 to $10.5 \mathrm{~K}$ depending on crystallite size and crystallinity (Murad et al., 1988; Murad and Cashion, 2004). An apparent blocking temperature of $>77 \mathrm{~K}$ for the $\mathrm{pH} 7$ redox product indicated the presence of a $\mathrm{Fe}$ (III) oxide with some difference in magnetic properties from ferrihydrite. Collectively, the RT and $77 \mathrm{~K}$ spectra of the $\mathrm{pH} 7$ precipitate were virtually identical to those reported for $4 \mathrm{~nm}$ magnetite (Goya et al., 2003). The $\mathrm{pH} 8$ precipitate also showed an increase in magnetic order at $77 \mathrm{~K}$ (Fig. 11b), albeit not as large as at $\mathrm{pH} 7$, with enhanced spectral area associated with the sextet features observed at RT indicating thermal relaxation associated with magnetite particles that were nominally $<10 \mathrm{~nm}$ in size (Goya et al., 2003).

The residual central doublet in the $\mathrm{pH} 8$ sample at $77 \mathrm{~K}$ (Fig. 11b) could result from the presence of ferrihydrite or another, fine-grained $\mathrm{Fe}(\mathrm{III})$ oxide exhibiting superparamagnetic relaxation. Ferrihydrite was the most defensible choice given the Fe-EXAFS spectra and fitting results (Fig. 9b). The doublet was also observed at lower intensity in the $77 \mathrm{~K}$ spectrum of the $\mathrm{pH} 6.8$ precipitate (data not shown), indicating the presence of ferrihydrite in this sample as well. Such features have not been observed in the $77 \mathrm{~K}$ Mössbauer spectrum of fine-grained stoichiometric magnetite (McNab et al., 1968; Gee et al., 2003; Goya et al., 2003) or fine-grained maghemite (da Costa et al., 1998). However, Jolivet et al. (1992) noted a similar Mössbauer spectra at $80 \mathrm{~K}$ for a $4.1 \mathrm{~nm}$ reaction product of $\mathrm{Fe}$ (II) with ferrihydrite. They speculated that this phase was a $\mathrm{Fe}(\mathrm{II})$-induced transformation product of ferrihydrite that exhibited: (i) nascent spinel structure, (ii) poor long range order, and (iii) tetrahedral site vacancies. Their variable temperature measurements implied a blocking temperature for this phase of approximately $60 \mathrm{~K}$, above that of ferrihydrite, and near that observed here.

\subsection{Reaction of the $\mathrm{Fe} / \mathrm{Tc}$ precipitates with molecular oxygen}

The $\mathrm{Fe} / \mathrm{Tc}$ particles characterized in Section 3.3 were subjected to oxidation in buffered suspensions that were bubbled with air at a rate that was sufficient to maintain oxygen saturation in the aqueous phase. The oxidation experiments were intended to provide additional, but indirect, evidence for the potential mode of Tc(IV) association with the $\mathrm{Fe} / \mathrm{Tc}$ precipitate. It was hypothesized that adsorbed $\mathrm{Tc}(\mathrm{IV})$ would be oxidized and released rapidly, while the reaction of structural $\mathrm{Tc}(\mathrm{IV})$ would be slower and incomplete. The small masses of the $\mathrm{Fe} / \mathrm{Tc}$ precipitates limited: (i) direct analyses of $\mathrm{Fe}(\mathrm{II})$ content by acid extraction, and (ii) long duration experiments.

\subsubsection{Oxidative solubilization of Tc(VII)}

The release of pertechnetate from the $\mathrm{pH} 6.8$ and 7 precipitates showed an approximate linear increase with time (Fig. 13), consistent with pseudo-zero-order kinetics. Approximately $10 \%$ of the precipitated $\mathrm{Tc}(\mathrm{IV})$ was oxidized and released as $\mathrm{Tc}(\mathrm{VII})$ to the aqueous phase within 5 days. The small mass of $\mathrm{Fe} / \mathrm{Tc}$ precipitate prevented further sampling past this time point. The $\mathrm{pH} 8 \mathrm{Fe} / \mathrm{Tc}$ precipitate showed a more rapid initial release (up to $4 \mathrm{~h}$ ), followed by a period of significantly slower, linear dissolution kinetics. Only $7 \%$ of the precipitated Tc(IV) was oxidized and released from the $\mathrm{pH} 8$ product over the course of 5 days of oxygen exposure. Dissolution rates were calculated from the slope of the linear portion of these plots (Table 5), and these ranged between 0.3 and $1.7 \mu \mathrm{mol} \mathrm{Tc} / \mathrm{g}$ solid/h. The dissolution rates were ordered inversely with the buffered experimental $\mathrm{pH}$ values that applied during reaction and precipitation. The oxidation rate of $\mathrm{Tc}(\mathrm{IV})$ decreased with increasing $\mathrm{Fe}(\mathrm{II})$ concentration in the precipitate. Suspension $\mathrm{pH}$ was monitored during the oxidation of all four samples and it was found to be constant over the course of the experiments. These rates were significantly slower than the oxidation rate of fine-grained $\mathrm{TcO}_{2} \cdot n \mathrm{H}_{2} \mathrm{O}(\sim 11.9 \mu \mathrm{mol}$ $\mathrm{Tc} / \mathrm{g}$ solid/h) that was treated in the same manner where $67 \%$ of the precipitate dissolved in 4 days. The release of $\mathrm{Tc}$ (VII) from the $\mathrm{Fe} / \mathrm{Tc}$ precipitates was significantly slower and less extensive then anticipated, given the oxidation/dissolution behaviour of $\mathrm{TcO}_{2} \cdot n \mathrm{H}_{2} \mathrm{O}$. The results implied that $\mathrm{Tc}(\mathrm{IV})$ was protected against oxidation by structural incor- 


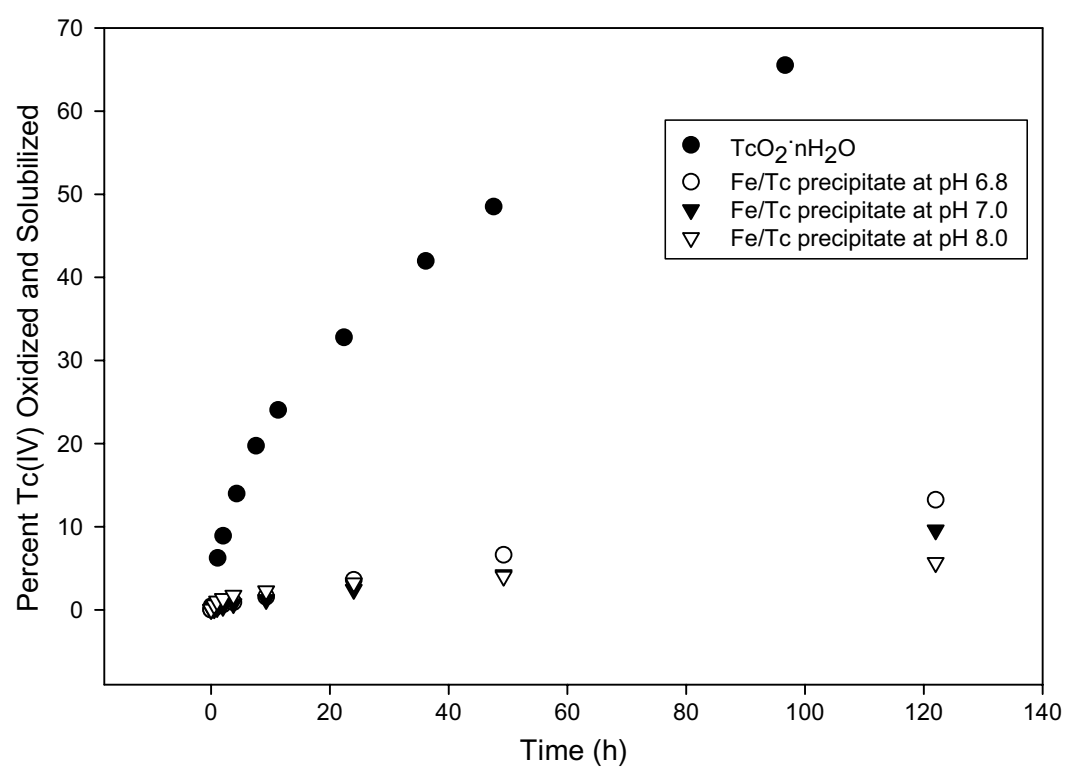

Fig. 13. Oxidative $\mathrm{Tc}(\mathrm{VII})$ release from $\mathrm{Tc}(\mathrm{IV}) \mathrm{O}_{2} \cdot n \mathrm{H}_{2} \mathrm{O}$ and the $\mathrm{pH} 6.8,7$ and $8 \mathrm{Fe} / \mathrm{Tc}$ precipitates.

Table 5

Oxidative dissolution rate of Tc

\begin{tabular}{lcl}
\hline $\mathrm{pH}$ & $\begin{array}{l}\text { Solid concentration } \\
(\mathrm{mg} / \mathrm{L})\end{array}$ & $\begin{array}{l}\text { Tc dissolution rate } \\
(\mu \mathrm{mol} \mathrm{Tc} / \mathrm{g} \text { solid/h })\end{array}$ \\
\hline 6.8 & 2.95 & 1.7 \\
7.0 & 3.88 & 1.3 \\
8.0 & 11.32 & 0.3 \\
\hline
\end{tabular}

poration or veneering by oxidized $\mathrm{Fe}$ in the $\mathrm{Fe} / \mathrm{Tc}$ precipitates; or that oxidized Tc(IV) was unable to diffuse to the bulk aqueous phase from intracrystalline domains.

\subsubsection{TEM analyses of the oxidized solids}

The oxidized residues from the $\mathrm{pH} 6.8$ and $\mathrm{pH} 7.0 \mathrm{Fe} / \mathrm{Tc}$ precipitates were similar in character. These, in turn, were similar to the $\mathrm{pH} 6.8$ reduced material (Fig. 7), and were characterized by the presence of somatoidal or "needlelike" precipitates up to $50 \mathrm{~nm}$ long embedded in finegrained material (Fig. 14). SAED of a $0.5 \mu \mathrm{m}$-diameter area of the $\mathrm{pH} 7 \mathrm{Fe} / \mathrm{Tc}$ precipitate (Fig. 7c) showed lines at $0.245,0.215,0.164$, and $0.144 \mathrm{~nm}$ that were virtually identical to the unoxidized samples and that qualitatively equated with magnetite. There was no apparent global mineralogic change upon oxidation. EDS analysis of the somatoids and fine-grained materials in the $\mathrm{pH} 6.8$ and 7.0 precipitates showed greater variability after oxidation, but no appreciable overall difference in composition from one another, averaging $85-88 \%$ atom $\mathrm{Fe}$ and $15-12 \%$ atom Tc. The observed Tc concentration in the solids changed little with oxidation.

The oxidized $\mathrm{pH} 8 \mathrm{Fe} / \mathrm{Tc}$ precipitates were comprised of ca $50-400 \mathrm{~nm}$ flat hexagonal crystals with closely associated fine-grained material that covered and connected the larger crystallites (Fig. 15). The hexagonal crystals yielded wellpronounced diffraction lines of $0.270 \mathrm{~nm}$, the most intense diffraction maxima for hematite $[I(\mathrm{f})=100 ; \quad(\mathrm{hkl})=$ (104)]. There was significant difference in the Fe:Tc ratio of the fine-grained material $(88 \%: 12 \%)$ as compared to the hexagonal crystallites $(96-100 \%: 4-0 \%)$, Fig. 15, based on EDS measurements performed with a $100 \mathrm{~nm}$ probe diameter. It appeared that some of the Tc signal from the hexagonal crystallites may have originated from finegrained materials on their surface.

\section{DISCUSSION}

\subsection{The reduction reaction}

Our observations of homogeneous $\mathrm{Tc}(\mathrm{VII})$ reduction contrast with the experimental results of Cui and Eriksen (1996a) who found no homogeneous Tc(VII) reduction by $\mathrm{Fe}(\mathrm{II})_{\mathrm{aq}}$ at circumneutral $\mathrm{pH}$. These authors contacted $\mathrm{Tc}$ (VII) $\left(3.3 \times 10^{-7} \mathrm{~mol} / \mathrm{L}\right)$ with $\mathrm{Fe}(\mathrm{II})_{\mathrm{TOT}}=5.8 \times 10^{-5}$ $\mathrm{mol} / \mathrm{L}$ in glass reaction vessels at $\mathrm{pH} 7$, and noted a significant reduction in $\mathrm{pH}(\sim 1.5$ units $), \mathrm{Fe}(\mathrm{II})_{\mathrm{aq}}(20.7 \%)$, and Tc(VII) (18\%). Following this observation, they coated the interiors of their glass reaction vessels with hexadimethyldisilazane, and saw little change in $\mathrm{Fe}(\mathrm{II})_{\mathrm{aq}}, \mathrm{Tc}(\mathrm{VII})$, or $\mathrm{pH}$ under comparable experimental conditions; concluding that adsorbed $\mathrm{Fe}(\mathrm{II})$ to the glass vessel wall was the reductant in the early experiment.

Our experiments were not performed in coated glass, yet we observed no reduction of $\mathrm{Tc}(\mathrm{VII})$ at $\mathrm{pH} 7$ with $\mathrm{Fe}(\mathrm{II})_{\mathrm{aq}}=5.0 \times 10^{-5} \mathrm{~mol} / \mathrm{L}$ over the time period of the Cui and Ericksen experiment (2750 min or 1.9 d; Fig. 3). Moreover we observed no glass discoloration later in the experiment that would result if adsorbed Fe(II) on vessel walls was oxidized by Tc(VII), and hydrolyzed and precipitated in place. We contend that the homogeneous reduction reaction is slow and promoted by hydrolyzed $\mathrm{Fe}(\mathrm{II})$ aqueous species as noted for $\mathrm{Cr}(\mathrm{VI})$ reduction. A measure of the reaction slowness can be gained by comparing our 
a

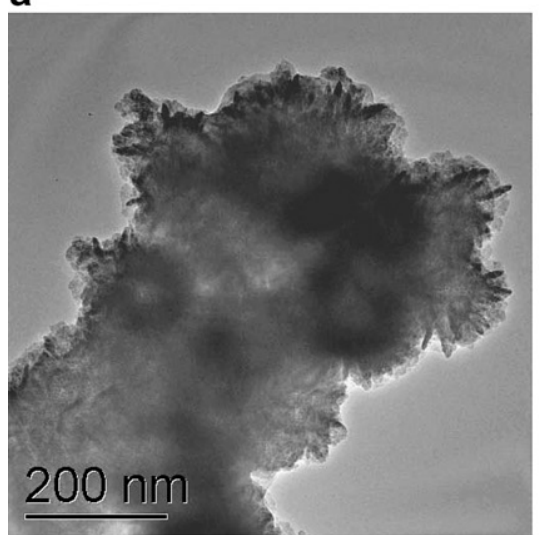

b

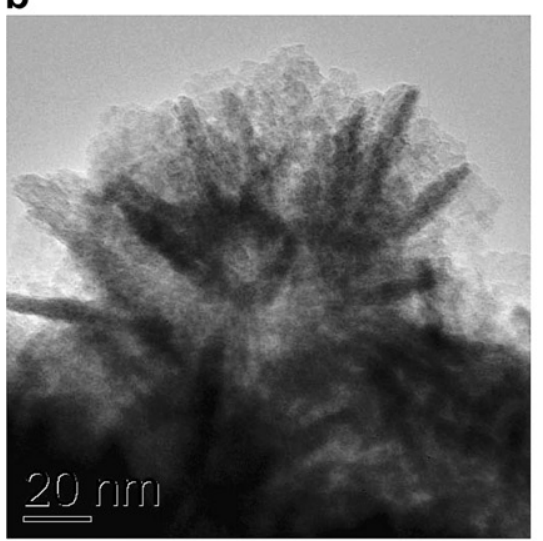

c

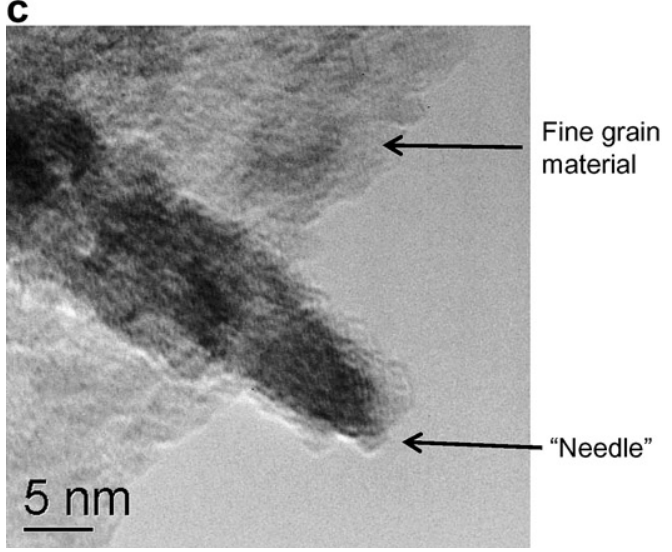

Fig. 14. Transmission electron micrographs $(\mathrm{a}-\mathrm{c})$ for the $\mathrm{pH} 7$ $\mathrm{Fe} / \mathrm{Tc}$ precipitate after 9.4 days of air oxidation.

rate of homogeneous $\mathrm{Tc}(\mathrm{VII})$ reduction as calculated at $\mathrm{pH}$ 7 with $0.05 \mathrm{mmol} / \mathrm{L} \mathrm{Fe}(\mathrm{II})$ (e.g., $k_{1}=0.005 \mathrm{day}^{-1}$ ) with the rate reported by Pettine et al. (1998) for $\mathrm{Cr}(\mathrm{VI}) \mathrm{O}_{4}{ }^{2-}$ reduction under comparable experimental conditions (e.g., $\mathrm{pH} \approx 6.9-7.0$ and $\left.\left[\mathrm{Fe}(\mathrm{II})_{\mathrm{aq}}\right] \approx 0.04 \mathrm{mmol} / \mathrm{L}\right)$. The ratio of reaction rates $\left(k_{1-\mathrm{Cr}(\mathrm{VI})} / k_{1-\mathrm{Tc}(\mathrm{VII})}\right)$ was $2.5 \times 10^{4}$, underscoring the slow rate of homogeneous $\mathrm{Tc}(\mathrm{VII})$ reduction. This slow rate is a possible consequence of the very low redox potentials required for the one and two electron transfer reactions leading to the potential $\mathrm{Tc}(\mathrm{VI})\left(\mathrm{TcO}_{4}{ }^{2-}\right.$, $\left.E^{\circ}=-0.64 \mathrm{~V}\right)$ and $\operatorname{Tc}(\mathrm{V})\left(E^{\circ}=-0.60 \mathrm{~V}\right)$ intermediate species, that are unstable and disproportionate (Founta et al., 1987; Rard et al., 1999). Our observation of homogeneous reduction was enabled by higher $\mathrm{Fe}(\mathrm{II})$ concentrations $(0.05-0.8 \mathrm{mmol} / \mathrm{L})$ as compared to $0.0064-0.12 \mathrm{mmol} / \mathrm{L}$ by (Cui and Eriksen, 1996a), and longer reaction times $(>14,000 \mathrm{~h}$ or $10 \mathrm{~d})$.

The empirical observations of an increase in the apparent reduction rate of $\mathrm{Tc}(\mathrm{VII})$ with both $\mathrm{Fe}(\mathrm{II})$ concentration and $\mathrm{pH}$ were fully consistent with comparable observations made by Sedlak and Chan (1997) for Cr(VI). With regard to the $\mathrm{pH}$ effect, ferrous iron hydrolysis apparently decreases the activation energy for electron transfer and increases the electron density of the metal ion center to make it kinetically more reactive (Davies and Morgan, 1988; Wehrli, 1990; Stumm, 1992; Sedlak and Chan, 1997). However, there are major differences in the redox properties of the intermediate valence states of $\mathrm{Cr}$ and $\mathrm{Tc}$ that may affect their comparative kinetic behavior. Unlike $\mathrm{Cr}(\mathrm{VI})$, our homogeneous reduction data did not conform to a pseudo-first order model, as plots of $\ln \left[C_{t} / C_{\mathrm{o}}\right]$ versus time showed curvilinear behaviour (e.g., increasing rate with reaction progress) even before the obvious onset of heterogeneous reduction (Fig. 4a). The acceleration in reduction, or autocatalysis by reaction intermediates or products, was believed to represent an evolution from homogeneous to heterogeneous reaction. Thus, the reaction domain was not classically homogeneous. The oxidation of $\mathrm{Fe}(\mathrm{II})_{\mathrm{aq}}$ by $\mathrm{Tc}(\mathrm{VII})$ yielded $\mathrm{Fe}(\mathrm{III})$ that hydrolyzed and quickly precipitated as a poorly crystalline oxyhydroxide because of its low solubility at circumneutral $\mathrm{pH}$. A breakpoint between homogeneous and heterogeneous reduction was observed for four of the $\mathrm{pH} 7$ experiments after the oxidation of $0.01-0.015 \mathrm{mmol} / \mathrm{L}$ of $\mathrm{Fe}(\mathrm{III})$, possibly signifying the presence of a threshold $\mathrm{Fe}(\mathrm{III})_{\mathrm{aq}}$ supersaturation value or $\mathrm{Fe}(\mathrm{III})$ oxide concentration for heterogeneous reduction. This concentration was approximately 100 times the solubility of ferrihydrite at this $\mathrm{pH}$ (Cornell and Schwertmann, 2000). It is possible that the interaction of $\mathrm{Fe}(\mathrm{II})$ and/or $\mathrm{Tc}$ (VII) with hydrolyzed Fe(III) clusters and other precursors of $\mathrm{Fe}(\mathrm{III})$ precipitates enhanced the kinetic reactivity of $\mathrm{Fe}(\mathrm{II})$ (and its hydrolyzed forms) with $\mathrm{Tc}(\mathrm{VII})$ during the "homogeneous phase".

Heterogeneous electron transfer promoted by sorbed $\mathrm{Fe}(\mathrm{II})$ was evident by a marked acceleration in $\mathrm{Tc}(\mathrm{VII})$ reduction rate that paralleled the observance of turbidity and $\mathrm{Fe}(\mathrm{III})$ precipitation in the batch reactors. Heterogeneous reduction appeared to be the primary observed process at higher $\mathrm{Fe}(\mathrm{II})$ concentrations and $\mathrm{pH}$. $\mathrm{Fe}(\mathrm{II})$ is strongly absorbed by ferrihydrite and crystalline $\mathrm{Fe}(\mathrm{III})$ oxides (Jeon et al., 2003), and significant residual Fe(II) was observed in the Fe/Tc precipitates by Fe-XANES analyses (Fig. 8). Fe(II) sorption by Fe(II) oxides lowers the redox potential of $\mathrm{Fe}(\mathrm{II})$ (Silvester et al., 2005 and references therein), and concentrates $\mathrm{Fe}(\mathrm{II})$ to facilitate multi-electron redox reactions (Cui and Eriksen, 1996a; Amonette et al., 2000). In an unpublished study by our laboratory, we have observed very rapid $\mathrm{Tc}(\mathrm{VII})$ reduction by $\mathrm{Fe}(\mathrm{II})$ sorbed to hematite and goethite. Similarly, subsurface sediments with sorbed $\mathrm{Fe}(\mathrm{II})$ were effective reductants of $\mathrm{Tc}(\mathrm{VII})$ at circumneutral $\mathrm{pH}$, displaying reaction half-lives ranging from 


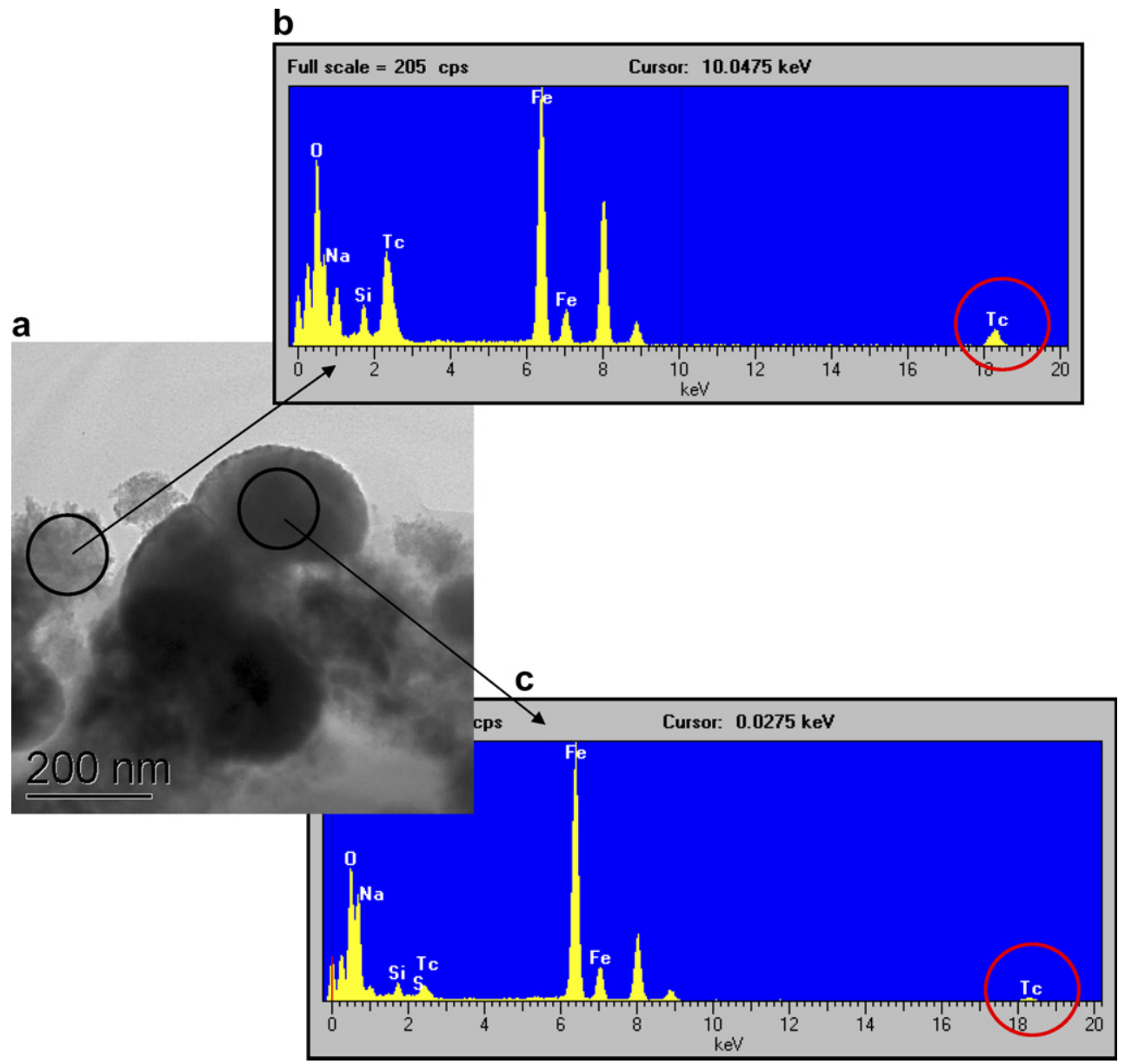

Fig. 15. Transmission electron micrograph (a) and energy dispersive spectroscopic analysis, (b) and, (c) of the $\mathrm{pH} 8 \mathrm{Fe} / \mathrm{Tc}$ precipitate after 9.4 days of air oxidation.

ca. $1 \mathrm{~min}$ to $3 \mathrm{~h}$ and with rates increasing with sorbed $\mathrm{Fe}(\mathrm{II})$ concentration (Fredrickson et al., 2004). The sediment displaying the most rapid heterogeneous reduction in this series (Eatontown) contained small crystallites of $\mathrm{Fe}(\mathrm{III})$ oxides. Moreover, magnetite, an apparent reaction product in these experiments, is also a strong heterogeneous reductant of Tc(VII) (Cui and Eriksen, 1996b; Lloyd et al., 2000).

\subsection{Fe in the redox reaction product}

The precipitates contained a mixture of $\mathrm{Fe}(\mathrm{II}), \mathrm{Fe}(\mathrm{III})$, and Tc(IV). Integrating the results of wet chemical, EDS, and XANES analyses yielded the following nominal compositions for the precipitates: (i) at $\mathrm{pH} 7-12.9 \% \mathrm{Fe}(\mathrm{II})$, $72.9 \% \mathrm{Fe}(\mathrm{III})$ and $14.2 \% \mathrm{Tc}(\mathrm{IV})$, with $\mathrm{Fe}_{\mathrm{TOT}} / \mathrm{Tc}(\mathrm{IV})=$ $6.04, \mathrm{Fe}(\mathrm{III}) / \mathrm{Tc}(\mathrm{IV})=5.13$, and $\mathrm{Fe}(\mathrm{II}) / \mathrm{Fe}(\mathrm{III})=0.18$, and (ii) at $\mathrm{pH} 8-21.7 \% \mathrm{Fe}(\mathrm{II}), 65.0 \% \mathrm{Fe}(\mathrm{III})$, and $13.3 \%$ $\mathrm{Tc}(\mathrm{IV})$, with $\mathrm{Fe}_{\mathrm{TOT}} / \mathrm{Tc}(\mathrm{IV})=6.51, \mathrm{Fe}(\mathrm{III}) / \mathrm{Tc}(\mathrm{IV})=4.88$, and $\mathrm{Fe}(\mathrm{II}) / \mathrm{Fe}(\mathrm{III})=0.33$. The $\mathrm{Fe}(\mathrm{III}) / \mathrm{Tc}(\mathrm{IV})$ ratios for both precipitates were in excess of the stoichiometry (3) of the redox reaction (Eq. (3)), indicating uncertainty in the Fe valence quantification by XANES, or the post experiment oxidation of Fe(II). Tc XANES measurements, however, indicated no Tc(IV) oxidation, and for the purpose of further discussion we assume that the XANES-determined $\mathrm{Fe}(\mathrm{II}) / \mathrm{Fe}(\mathrm{III})$ ratios were representative of the redox product, while recognizing the unexplained disparity. Our observations of an $\mathrm{Fe}(\mathrm{II})$-enriched redox product contrasted with those of Hansel et al. (2003a) and Wielinga et al. (2001), who observed no $\mathrm{Fe}(\mathrm{II})$ in $\mathrm{Fe}(\mathrm{III}) / \mathrm{Cr}$ (III) hydroxide precipitates resulting from $\mathrm{Cr}(\mathrm{VI}) \mathrm{O}_{4}{ }^{2-}$ reduction by biogenic $\mathrm{Fe}(\mathrm{II})_{\mathrm{aq}}$. Initial redox precipitates in their system exhibited a ferrihydrite-like structure and $\mathrm{Fe}(\mathrm{III}) / \mathrm{Cr}(\mathrm{III})=2.5$, slightly below the anticipated stoichiometry of 3.

The $\mathrm{Fe} / \mathrm{Tc}$ solids exhibited ferrimagnetic behavior implying at least some conversion to magnetite. The presence of tetrahedral Fe-bonding as noted in the Fe-XANES spectra, the dual sextet Mössbauer pattern in the RT spectrum and results of Fe-EXAFS fitting for the $\mathrm{pH} 8$ precipitate, and SAED d-spacings all supported the plausible presence of some magnetite. However, we cannot entirely discount the possibility that maghemite rather than magnetite was present, as these two phases are difficult to differentiate by X-ray diffraction, Mössbauer spectroscopy, and X-ray absorption spectroscopy because of their similar structure and possibility for solid solution formation (e.g., Hanzlik et al., 1996; McCormick and Adriaens, 2004; 
Williams et al., 2005). The high angle (553) diffraction doublet $\left(\sim 89-91^{\circ} 2 \theta\right)$ and several other low intensity diffraction peaks can allow discrimination between magnetite and maghemite (Daniels and Rosencwaig, 1969), but we did not have sufficient masses of the $\mathrm{Fe} / \mathrm{Tc}$ precipitates to perform this analysis.

$\mathrm{Fe}(\mathrm{II})_{\mathrm{aq}}$ is very reactive with ferrihydrite at circumneutral pH (Cornell and Schwertmann, 2000; Zachara et al., 2002; Hansel et al., 2003b; Jeon et al., 2003; Pederson et al., 2005), the presumed initial redox product (e.g., Hansel et al., 2003a), and can induce its transformation to more crystalline phases such as goethite, hematite, and magnetite depending on the $\mathrm{Fe}(\mathrm{II}) / \mathrm{Fe}(\mathrm{III})$ ratio and $\mathrm{pH}$ (Jolivet et al., 1992; Tronc et al., 1992; Zachara et al., 2002; Hansel et al., 2003b; Pederson et al., 2005). However the high Fe(II)/ $\mathrm{Fe}(\mathrm{III})$ ratio (1.5-24) in these experiments, which was determined by the initial $\mathrm{Fe}(\mathrm{II})_{\mathrm{aq}}$ and $\mathrm{Tc}(\mathrm{VII})$ concentrations, and the circumneutral to alkaline $\mathrm{pH}$, placed the reaction product in the magnetite stability field. The observation of more magnetite in the $\mathrm{pH} 8$ sample was consistent with its higher sorbed $\mathrm{Fe}(\mathrm{II})$ content and with past observations of conditions favoring magnetite formation.

The $\mathrm{Fe} / \mathrm{Tc}$ redox products had a significantly lower $\mathrm{Fe}(\mathrm{II}) / \mathrm{Fe}(\mathrm{III})$ ratio $(0.18-0.33)$ than stoichiometric magnetite $(0.5)$. If all the $\mathrm{Fe}(\mathrm{II})$ in the reaction products were assumed to reside in stoichiometric magnetite [Fe(II)$\left.\mathrm{Fe}(\mathrm{III})_{2} \mathrm{O}_{4}\right]$, then $25 \%$ of the $\mathrm{Fe}$ in the $\mathrm{pH} 7$ precipitate and $62 \%$ of the $\mathrm{Fe}$ in the $\mathrm{pH} 8$ precipitate could reside in this phase (according to XANES analysis). However, the results of EXAFS fitting suggested far lower magnetite contents: $0 \%$ for $\mathrm{pH} 7$ and $11 \%$ for $\mathrm{pH}$. The presence of paired sextets in the $\mathrm{pH} 8$ precipitate at RT (Fig. 8a), and infrequent SAED patterns consistent with crystalline magnetite (Fig. 7a) provided qualitative corroboration of EXAFS fitting results. More consistent with our observations was the presence of poorly ordered, Fe(II)-substituted ferrihydrite possibly representing protomagnetite. This phase exhibited diffuse electron diffraction rings signifying more disorder than 6-line ferrihydrite; perhaps it is of 2-line form.

In previous research on the biotransformation of ferrihydrite (Fredrickson et al., 1998), we noted formation of a black ferrimagnetic transformation product with magnetite-like $\mathrm{Fe}(\mathrm{II}): \mathrm{Fe}(\mathrm{III})$ stoichiometry that did not exhibit diffraction peaks of magnetite. Recent Fe-EXAFS measurements of a similar Fe(II)-enriched phase showed a ferrihydrite-like EXAFS spectrum almost identical to the $\mathrm{pH} 7$ and $\mathrm{pH} 8$ samples investigated here (data not shown). An $\mathrm{Fe}(\mathrm{II})$-enriched ferrihydrite was also observed as an intermediate product in the bacterial transformation of ferrihydrite to green rust, and this phase exhibited a similar X-ray diffraction pattern to ferrihydrite (Kukkadapu et al., 2004). Apparently, ferrihydrite can incorporate significant $\mathrm{Fe}(\mathrm{II})$ without appreciably changing its disordered structural character. Ongoing research by our group seeks to clarify this unexpected behavior of ferrihydrite.

Most have observed that the reaction of $\mathrm{Fe}(\mathrm{II})$ with ferrihydrite at $\mathrm{pH}$ above neutrality yields magnetite as the primary product when $\mathrm{Fe}(\mathrm{II}) / \mathrm{Fe}(\mathrm{III}) \geqslant 0.5$ (Sugimoto and Matijevic, 1980; Mann et al., 1989; Jolivet et al., 1992;
Tronc et al., 1992). Because Fe(III) in our experiments was generated by kinetic reaction of $\mathrm{Tc}(\mathrm{VII})$ with $\mathrm{Fe}(\mathrm{II})_{\mathrm{aq}}$, the $\mathrm{Fe}(\mathrm{II}) / \mathrm{Fe}$ (III) ratio followed a complex temporal trajectory, and, for the $\mathrm{pH} 8$ sample specifically, ranged from a nominally high value to one of 12 at experiment termination. Perhaps the incorporation of the large noted concentrations of $\mathrm{Tc}(\mathrm{IV})$ into the precipitate (ca. $12-15$ atom \%), in spite of its nearly equal ionic radii $(0.645 \AA)$ with $\mathrm{Fe}(\mathrm{III})$ $(0.640 \AA)$, inhibited the catalytic effect of Fe(II) on re-crystallization of the Fe(III) product (e.g., Pederson et al., 2005) and contributed to precipitate disorder. The coordination behavior of $\mathrm{Tc}(\mathrm{IV})$ apparently favors the formation of amorphous, rather than crystalline oxide solids at room temperature (Burnett et al., 1995; Rard et al., 1999; Lukens et al., 2002). Crystalline $\mathrm{Tc}(\mathrm{IV}) \mathrm{O}_{2}$, however, adopts the rutile $\left(\mathrm{TiO}_{2}\right)$ structure (Rogers et al., 1969; Vichot et al., 2002). Titanium(IV) (0.68§) substitutes widely in $\mathrm{Fe}(\mathrm{III})$ oxides (e.g., Fitzpatrick et al., 1978) and forms solid solution series in $\mathrm{Fe}(\mathrm{II}) / \mathrm{Fe}(\mathrm{III})$ spinels such as ulvospinel $\left\{\mathrm{Fe}(\mathrm{II})[\mathrm{Fe}(\mathrm{II}) \mathrm{Ti}(\mathrm{IV})] \mathrm{O}_{4}\right\}$ and in maghemite $\left[\mathrm{Fe}_{2} \mathrm{TiO}_{5}\right.$; Lindsley (1976)]. Evidence was sought here, but not found, for the formation of comparable Tc(IV)-substituted, crystalline $\mathrm{Fe}(\mathrm{II}) / \mathrm{Fe}(\mathrm{III})$ oxides.

\section{3. $T c$ in the redox reaction product}

We had initially speculated that Tc(IV) would exist in a structural, co-precipitated molecular environment as defined by multiple second-shell Fe neighbors based on EXAFS analysis. This hypothesis was based on the belief that $\mathrm{Tc}(\mathrm{IV})$ and $\mathrm{Fe}(\mathrm{III})$ would precipitate in intimate association after either homogeneous or heterogeneous reaction. Given the known tendency of $\mathrm{Tc}(\mathrm{IV})$ to favor a hexacoordinate motif in aqueous complexes (Ben Said et al., 2000; Vichot et al., 2002) and crystalline solids (Rogers et al., 1969; Vichot et al., 2002), we further speculated that sorbed Tc(IV) would exist in an octahedral environment distributed within the Fe(III) oxide structure. In contrast, the best fit model to the Tc-EXAFS data was found to be a single $\mathrm{Tc}(\mathrm{IV})_{2} \mathrm{O}_{10}$ octahedral dimer linked in edge-sharing mode to a single $\mathrm{Fe}(\mathrm{III})-\mathrm{O}$ octahedral site in ferrihydrite. This model was different from the extended $\mathrm{Tc}(\mathrm{IV}) \mathrm{O}_{2} \cdot n \mathrm{H}_{2} \mathrm{O}$ octahedral chain model of Lukens et al. (2002) that described the structure of Tc(IV) products resulting from the reaction of $\mathrm{Tc}(\mathrm{VII})$ with a variety of environmental reductants including pyrite, magnetite, humic substances, and layer lattice silicates suspended in reducing groundwater (Maes et al., 2004). Their starting $\mathrm{Tc}(\mathrm{VII})$ concentrations $\left(2.2 \times 10^{-3} \mathrm{~mol} / \mathrm{L}\right)$ however, were over 200 times larger then those used in the present experiments $\left(1.1 \times 10^{-5} \mathrm{~mol} / \mathrm{L}\right)$.

The edge-sharing Tc(IV) dimer model was conceptually consistent with the formation of a polymeric surface complex along grain boundaries of individual nm-sized crystallites in larger particle aggregates, or at discontinuous point defects within disordered ferrihydrite. The approximate $15 \%$ atomic fraction of Tc(IV) in the precipitates could, marginally, be accommodated as a dimeric surface complex if the precipitated $\mathrm{Fe}(\mathrm{III})$ exhibited a site density comparable to rapidly precipitated hydrous ferric oxide 
$\left[\mathrm{N}_{\mathrm{s} 2}=0.2 \mathrm{~mol} / \mathrm{mol} \mathrm{Fe}\right.$; Dzombak and Morel (1990)]. The Fe-EXAFS spectrum of the reference 6-line ferrihydrite was best modeled with a site occupancy of 0.5 , possibly indicating the presence of even more sites for incorporation of Tc(IV) dimers.

The predominant $\mathrm{Tc}(\mathrm{IV})$ aqueous species between $\mathrm{pH} 3$ to 10 is reported to be $\mathrm{TcO}(\mathrm{OH})_{2}{ }^{\circ}$ (aq) (Rard et al., 1999), which is thermodynamically equivalent to $\mathrm{Tc}(\mathrm{OH})_{4}\left(\mathrm{H}_{2} \mathrm{O}\right)_{2}{ }^{\circ}{ }_{(\text {aq }}$ (Rard et al., 1999; Ben Said et al., 2000). The molecular structure for this primary hydrolyzed species has been debated but not verified. A $\mathrm{Tc}(\mathrm{OH})_{4}\left(\mathrm{H}_{2} \mathrm{O}\right)_{2}{ }^{\circ}$ (aq) ogy to the Lukens chain model but with equatorial $\mathrm{OH}$ groups replacing edge-shared oxygens. However, (Vichot et al., 2002) documented the presence of polymeric Tc(IV) species (with $\mathrm{N}_{\mathrm{Tc}}>2$ ) at acidic $\mathrm{pH}$ with similar EXAFS signature to $\mathrm{Tc}(\mathrm{IV}) \mathrm{O}_{2} \cdot n \mathrm{H}_{2} \mathrm{O}$, and speculated that these were precursors to precipitates. The formation of aqueous Tc(IV) dimers has also been suggested (Sundrehagen, 1979). Our structural model for the $\mathrm{Fe} / \mathrm{Tc}$ precipitate may therefore be consistent with a neutral, dimeric surface complex, $(\mathrm{OH})_{2}\left(\mathrm{H}_{2} \mathrm{O}\right)_{2} \mathrm{Tc}(\mathrm{O})_{2}\left(\mathrm{H}_{2} \mathrm{O}\right)_{2} \mathrm{Tc}\left(\mathrm{O}^{-}\right)_{2(\mathrm{~s})}$, where hydroxyls are in the equatorial plane of the distal Tc(IV) octahedron, waters are in the axial planes of both Tc(IV) octahedrons, oxygens bridge the equatorial plane between distal and proximate Tc(IV) centers, and equatorial oxygens $\left(\mathrm{O}^{-}\right)$in the proximate $\mathrm{Tc}(\mathrm{IV})$ octahedron are edge shared with $\mathrm{Fe}(\mathrm{III})$ in octahedral coordination.

The oxidation behavior of the precipitated Tc(IV) further suggested that its sorption state was not simply a surface complex on exposed surfaces of the ferrihydrite, but involved a more intimate association with internal domains of the precipitate. Its oxidation rate was significantly slower than $\mathrm{Tc}(\mathrm{IV}) \mathrm{O}_{2} \cdot n \mathrm{H}_{2} \mathrm{O}$, suggesting that the dimeric complexes were in intra-aggregate domains or possibly unoccupied octahedral $\mathrm{Fe}(\mathrm{III})$ sites within individual crystallites that were restrictive to oxygen diffusion. XANES analyses of the oxidized precipitates showed a decreased $\mathrm{Fe}(\mathrm{II}) / \mathrm{Tc}(\mathrm{IV})$ ratio and lingering $\mathrm{Tc}(\mathrm{IV})$ in concentration equal to the unoxidized fraction. These intraparticle domains may have become further isolated from molecular oxygen through $\mathrm{Fe}(\mathrm{II})$ oxidation and $\mathrm{Fe}(\mathrm{III})$ precipitation in diffusion paths during the oxidation experiment, as increased $\mathrm{Fe}(\mathrm{II})$ in the precipitate was associated with a slower oxidation rate. The high $\mathrm{Fe}(\mathrm{II})$ content of the ferrihydrite may have functioned as an antioxidant for $\mathrm{Tc}(\mathrm{IV})$, with the resulting $\mathrm{Fe}(\mathrm{III})$ acting to further stabilize coordinated $\mathrm{Tc}(\mathrm{IV})$ in the $\mathrm{Fe}(\mathrm{III})$ oxide structure. Stabilized Tc(IV) apparently resided in the fine grained residual ferrihydrite, as TEM elemental analyses suggested that it did not incorporate into hematite that formed as an oxidation product in the $\mathrm{pH} 8$ material (Fig. 15). Burke et al. (2006b) recently studied the oxidation of sediment-bound Tc(IV), implied by EXAFS analysis to be $\mathrm{TcO}_{2} \cdot n \mathrm{H}_{2} \mathrm{O}$, that was formed by the reaction of $\mathrm{Tc}(\mathrm{VII})$ with biogenic $\mathrm{Fe}(\mathrm{II})$. These authors observed higher oxidation rates and extent for $\mathrm{Tc}(\mathrm{VII})$ then noted for our samples in Fig. 13, possibly reflecting the different molecular environments of Tc(IV) in the two materials as indicated by EXAFS measurements.

\section{ACKNOWLEDGMENTS}

This research was supported by the Environmental Remediation Sciences Program (ERSP), Office of Biological and Environmental Research (OBER), U.S. Department of Energy (DOE). The authors thank (i) Dr. Nancy Hess for commenting on the EXAFS analyses and the molecular forms of $\mathrm{Tc}(\mathrm{IV})$ hydrolysis species, and (ii) an anonymous reviewer made insightful comments on Tc reaction kinetics and intermediate species. Transmission electron microscopy and Mössbauer measurements were performed in the William R. Wiley Environmental Molecular Sciences Laboratory, a national scientific user facility sponsored by the Department of Energy's Office of Biological and Environmental Research and located at Pacific Northwest National Laboratory. PNNL is operated for the DOE by Battelle. Use of the Advanced Photon Source for XANES and EXAFS measurements was supported by the US DOE, Office of Science, under contract No. W-31-109-Eng-38.

\section{REFERENCES}

Allison J. D., Brown D. S., and Novo-Gradac, K. J. (1998) MINTEQA2/PRODEFA2, A Geochemical Assessment Model for Environmental Systems: User Manual Supplement for Version 4.0; U.S. Environmental Protection Agency: Washington, DC.

Amonette J. E., Workman D. J., Kennedy D. W., Fruchter J. S., and Gorby Y. A. (2000) Dechlorination of carbon tetrachloride by $\mathrm{Fe}(\mathrm{II})$ associated with goethite. Environ. Sci. Technol. 34, 4606-4613.

Ben Said K., Fattahi M., Musikas C., Revel R., and Abbe J. C. (2000) The speciation of Tc(IV) in chloride solutions. Radiochim. Acta 88, 567-571.

Bondietti E. A., and Francis C. W. (1979) Geologic migration potentials of Tc-99 and N-237. Science 203, 1337-1340.

Buerge I. J., and Hug S. J. (1997) Kinetics and pH dependence of chromium(VI) reduction by iron(II). Environ. Sci. Technol. 31, 1426-1432.

Burke I. T., Boothman C., Lloyd J. R., Mortimer R. J. G., Livens F. R., and Morris K. (2006a) Effects of progressive anoxia on the solubility of technetium in sediments. Environ. Sci. Technol. 39, 4109-4116.

Burke I. T., Boothman C., Lloyd J. R., Livens F. R., Charnock J. M., McBeth J. M., Mortimer R. J. G., and Morris K. (2006b) Reoxidation behavior of technetium, iron, and sulfur inestuarine sediments. Environ. Sci. Technol. 40, 3529-3535.

Burnett K. B., Campbell A. B., Jobe D. J., Lemire R. J., and Taylor P. (1995) Synthesis, characterization and heat of formation of the amorphous and crystalline forms of $\mathrm{TcO}_{2}$. Radiochim. Acta 69, 241-249.

Cornell R. M., and Schwertmann U. (2000) The Iron Oxides: Structure, Properties, Reactions, Occurrences and Uses. WILEY-VCH.

Cui D., and Eriksen T. E. (1996a) Reduction of pertechnetate by ferrous iron in solution: Influence of sorbed and precipitated Fe(II). Environ. Sci. Technol. 30, 2259-2262.

Cui D., and Eriksen T. E. (1996b) Reduction of pertechnetate in solution by heterogeneous electron transfer from Fe(II)-containing geological material. Environ. Sci. Technol. 30, 22632269.

da Costa G. M., De Grave E., and Vandenberghe R. E. (1998) Mössbauer studies of magnetite and Al-substituted maghemites. Hyperfine Inter. 117, 207-243.

Daniels J. M., and Rosencwaig A. (1969) Mössbauer spectroscopy of stoichiometric and non-stoichiometric magnetite. J. Phys. Chem. Solids 30, 1561-1571. 
Davies S. H. R., and Morgan J. J. (1988) Manganese(II) oxidation kinetics on oxide surfaces. J. Coll. Inter. Sci. 129(1), 63-77.

Drits V. A., Sakharov B. A., Salyn A. L., and Manceau A. (1993) Structural model for ferrihydrite. Clay Miner. 28, 185-207.

Dzombak D. A., and Morel F. M. M. (1990) Surface Complexation Modeling: Hydrous Ferric Oxides. John Wiley.

Eary L. E., and Rai D. (1988) Chromate removal from aqueous wastes by reduction with ferrous ion. Environ. Sci. Technol. 22, 972-977.

Eggleston R. A., and Fitzpatrick R. W. (1988) New data and a revised structural model for ferrihydrite. Clays Clay Miner. 36(2), 111-124.

Eriksen, T. E. and Cui, D. (1991). On the interaction of granite with $T c(I V)$ and $T c(V I I)$ in aqueous solution. SKB-TR-91-47. Swedish Nuclear Fuel and Waste Management Co., Stockholm.

Eriksen, T. E., Ndalamba, P., Cui, D., Bruno, J., Caceci, M., and Spahiu, K. (1993). Solubility of the redox-sensitive radionuclides ${ }^{99} \mathrm{Tc}$ and ${ }^{237} \mathrm{~Np}$ under reducing conditions in neutral to alkaline solution, effect of carbonate. SKB-TR-93-18. Swedish Nuclear Fuel and Waste Management Co., Stockholm.

Fendorf S. E., and Li G. (1996) Kinetics of chromate reduction by ferrous iron. Environ. Sci. Technol. 30, 1614-1617.

Fischer W. R., and Schwertmann U. (1974) The formation of hematite from amorphous iron(III)hydroxide. Clays Clay Miner. 23, 33-37.

Fitzpatrick R. W., Le Roux J., and Schwertmann U. (1978) Amorphous and crystalline titanium and iron-titanium oxides in synthetic preparations, at near ambient conditions, and in soil clays. Clays Clay Miner. 26(3), 189-201.

Founta A., Aikens D. A., and Clark H. M. (1987) Mechanism and kinetics of the stepwise voltammetric reduction of pertechnetate in alkaline solution to $\mathrm{Tc}(\mathrm{VI}), \mathrm{Tc}(\mathrm{V})$, and $\mathrm{Tc}(\mathrm{IV})$. J. Electroanal. Chem. 219, 221-246.

Fredrickson J. K., Zachara J. M., Kennedy D. W., Dong H., Onstott T. C., Hinman N. W., and Li S. W. (1998) Biogenic iron mineralization accompanying the dissimilatory reduction of hydrous ferric oxide by a ground water bacterium. Geochim. Cosmochim. Acta 62, 3239-3257.

Fredrickson J. K., Zachara J. M., Kennedy D. W., Kukkadapu R. K., McKinley J. P., Heald S. M., Liu C., and Plymale A. E. (2004) Reduction of $\mathrm{TcO}_{4}{ }^{-}$by sediment-associated biogenic $\mathrm{Fe}(\mathrm{II})$. Geochim. Cosmochim. Acta 68(15), 3171-3187.

Gee S. H., Hong Y. K., Erickson D. W., and Park M. H. (2003) Synthesis and aging effect of spherical magnetite $\left(\mathrm{Fe}_{3} \mathrm{O}_{4}\right)$ nanoparticles for biosensor applications. J. Appl. Phys. 93(10), 7560-7562.

Goya G. F., Berquo T. S., Fonseca F. C., and Morales M. P. (2003) Static and dynamic magnetic properties of spherical magnetite nanoparticles. J. Appl. Phys. 94(5), 3520-3528.

Hansel C. M., Wielinga B. W., and Fendorf S. (2003a) Structural and compositional evolution of $\mathrm{Cr} / \mathrm{Fe}$ solids after indirect chromate reduction by dissimilatory iron-reducing bacteria. Geochim. Cosmochim. Acta 67(3), 401-412.

Hansel C. M., Benner S. G., Neiss J., Dohnalkova A., Kukkadapu R. K., and Fendorf S. (2003b) Secondary mineralization pathways induced by dissimilatory iron reduction of ferrihydrite under advective flow. Geochim. Cosmochim. Acta 67(16), 2977-2992.

Hanzlik M., Petersen N., Keller R., and Schmidbauer E. (1996) Electron microscopy and ${ }^{57} \mathrm{Fe}$ Mössbauer spectra of $10 \mathrm{~nm}$ particles, intermediate in composition between $\mathrm{Fe}_{3} \mathrm{O}_{4}$ and $\mathrm{Fe}_{3} \mathrm{O}_{3}$, produced by bacteria. Geophys. Res. Lett. 23, 479-482.

Hess N. J., Yuanxian X., Rai D., and Conradson S. D. (2004) Thermodynamic model for the solubility of $\mathrm{TcO}_{2} \mathrm{xH}_{2} \mathrm{O}(\mathrm{am})$ in the Aqueous $\mathrm{Tc}(\mathrm{IV})-\mathrm{Na}^{+}-\mathrm{Cl}^{-}-\mathrm{H}^{+}-\mathrm{OH}^{-}-\mathrm{H}_{2} \mathrm{O}$ system. J. Sol. Chem. 33(2), 199-226.
ICDD. (2003) JCPDS Powder Diffraction Files, PDF. International Centre for Diffraction Data.

Istok J. D., Senko J. M., Krumholz L. R., Watson D., Bogle M. A., Peacock A., Chang J.-Y., and White D. C. (2004) In situ bioreduction of technetium and uranium in a nitrate-contaminated aquifer. Environ. Sci. Technol. 38, 468-475.

Janney D. E., Cowley J. M., and Buseck P. R. (2000a) Structure of synthetic 2-line ferrihydrite by electron nanodiffraction. Amer. Mineral. 85, 1180-1187.

Janney D. E., Cowley J. M., and Buseck P. R. (2000b) Transmission electron microscopy of synthetic 2- and 6-line ferrihydrite. Clays Clay Miner. 48, 111-119.

Jansen E., Kyek A., Schafer W., and Schwertmann U. (2002) The structure of six-line ferrihydrite. Appl. Phys. A 74, S1004 S1006.

Jeon B.-H., Dempsey B. A., and Burgos W. D. (2003) Kinetics and mechanisms for reactions of $\mathrm{Fe}(\mathrm{II})$ with iron(III) oxides. Environ. Sci. Technol. 37, 3309-3315.

Jeon B.-H., Dempsey B. A., Royer R. A., and Burgos W. D. (2004a) Low-temperature oxygen trap for maintaining strict anoxic conditions. J. Environ. Eng. ASCE 130(11), 1407-1410.

Jeon B.-H., Kelly S. D., Kemner K. M., Barnett M. O., Burgos W. D., Dempsey B. A., and Roden E. E. (2004b) Microbial reduction of U(VI) at the solid-water interface. Environ. Sci. Technol. 38(21), 5649-5655.

Jolivet J.-P., Belleville P., Tronc E., and Livage J. (1992) Influence of $\mathrm{Fe}(\mathrm{II})$ on the formation of the spinel iron oxide in alkaline medium. Clays Clay Miner. 40(5), 531-539.

Kukkadapu R. K., Zachara J. M., Fredrickson J. K., and Kennedy D. W. (2004) Biotransformation of synthetic 2-line silicaferrihydrite coprecipitates by a dissimilatory $\mathrm{Fe}(\mathrm{III})$-reducing bacterium:, Formation of carbonate green rust in the presence of phosphate. Geochim. Cosmochim. Acta 67, 1081-1087.

Lindsley D. H. (1976) The crystal chemistry and structure of oxide minerals as exemplified by the $\mathrm{Fe}-\mathrm{Ti}$ oxides. In Oxides Minerals, Reviews in Mineralogy 3 (ed. I. D. Rumble). Min. Soc. Am. Book Crafters, Inc., pp. L1-L60.

Liu C., Gorby Y. A., Zachara J. M., Fredrickson J. K., and Brown C. F. (2002) Reduction kinetics of Fe(III), Co(III), U(VI), $\mathrm{Cr}(\mathrm{VI})$, and $\mathrm{Tc}(\mathrm{VII})$ in cultures of dissimilatory metal-reducing bacteria. Biotechnol. Bioeng. 80(6), 638-649.

Lloyd J. R., and Macaskie L. E. (1996) A novel phosphorimagerbased technique for monitoring the microbial reduction of technetium. Appl. Environ. Microbiol. 62(2), 578-582.

Lloyd J. R., Sole V. A., Van Praagh C. V. G., and Lovley D. R. (2000) Direct and $\mathrm{Fe}(\mathrm{II})$-mediated reduction of technetium by Fe(III)-reducing bacteria. Appl. Environ. Microbiol. 66(9), 3743-3749.

Lukens, Jr., W. W., Bucher J. J., Edelstein N. M., and Shuh D. K. (2002) Products of pertechnetate radiolysis in highly alkaline solution: structure of $\mathrm{TcO}_{2} \times \mathrm{H}_{2} \mathrm{O}$. Environ. Sci. Technol. 36, 1124-1129.

Maes A., Geraedts K., Bruggeman C., Vancluysen J., Rossberg A., and Hennig C. (2004) Evidence for the interaction of technetium colloids with humic substances by X-ray absorption spectroscopy. Environ. Sci. Technol. 38, 2044-2051.

Mann S., Sparks N. H. C., Couling S. B., Larcombe M. C., and Frankel R. B. (1989) Crystallochemical characterization of magnetic spinels prepared from aqueous solution. J. Chem. Soc., Faraday Trans. I 85(9), 3033-3044.

McCormick M. L., and Adriaens P. (2004) Carbon tetrachloride transformation on the surface of nanoscale biogenic magnetite particles. Environ. Sci. Technol. 38, 1045-1053.

McNab T. K., Fox R. A., and Boyle A. J. F. (1968) Some magnetic properties of magnetite $\left(\mathrm{Fe}_{3} \mathrm{O}_{4}\right)$ microcrystals. J. Appl. Phys. 39(12), 5703-5711. 
Meyer R. E., Arnold W. D., Case F. I., and O'Kelley G. D. (1991) Solubilities of Tc(IV) oxides. Radiochim. Acta 55, 11-18.

Murad E., and Cashion J. (2004) Mössbauer Spectroscopy of Environmental Materials and their Industrial Utilization. Kluwer Academic Publishers, Dordrecht.

Murad E., and Schwertmann U. (1993) Temporal stability of a fine-grained magnetite. Clays Clay Miner. 41(1), 111-113.

Murad E., Bowen L. H., Long G. J., and Quin T. G. (1988) The influence of crystallinity on magnetic ordering in natural ferrihydrites. Clay Miner. 23, 161-173.

Pederson H. D., Postma D., Jakobsen R., and Larsen O. (2005) Fast transformation of iron oxyhydroxides by the catalytic action of aqueous Fe(II). Geochim. Cosmochim. Acta 69(16), 3967-3977.

Pettine M., D'Ottone L., Campanella L., Millero F. J., and Passino R. (1998) The reduction of chromium(VI) by iron(II) in aqueous solutions. Geochim. Cosmochim. Acta 62(9), 15091519.

Rancourt D. G., Thibault P.-J., Mavrocordatos D., and Lamarche G. (2005) Hydrous ferric oxide precipitation in the presence of nonmetabolizing bacteria: constraints on the mechanism of a biotic effect. Geochim. Cosmochim. Acta 69(3), 553-577.

Rard J. A., Rand M. H., Anderegg G., and Wanner H. (1999) Chemical Thermodynamics of Technetium. Elsevier, Amsterdam.

Ravel B., and Newville M. (2005) ATHENA, ARTEMIS, HEPHAESTUS; data analysis for X-ray absorption spectroscopy using IFEFFIT. J. Synchrotron Rad. 12(4), $537-541$.

Rehr J. J., and Albers R. C. (2000) Theoretical approaches to Xray absorption fine structure. Rev. Mod. Phys. 72, 621-654.

Rogers D. B., Shannon R. D., Sleight A. W., and Gillson J. L. (1969) Crystal chemistry of metal dioxides with rutile-related structures. Inorg. Chem. 8(4), 841-849.

Sass B. M., and Rai D. (1987) Solubility of amorphous chromium(III)-iron(III) hydroxide solid solutions. Inorg. Chem. 26, 2228-2232.

Sedlak D. L., and Chan P. G. (1997) Reduction of hexavalent chromium by ferrous iron. Geochim. Cosmochim. Acta 61(11), 2185-2192.

Silvester E., Charlet L., Tournassat C., Gehin A., Greneche J.-M., and Liger E. (2005) Redox potential measurements and Mossbauer spectrometry of $\mathrm{Fe}^{\mathrm{II}}$ adsorbed onto $\mathrm{Fe}^{\mathrm{III}}$ (oxyhydr)oxides. Geochim. Cosmochim. Acta 69(20), 4801-4815.

Stumm W. (1992) Chemistry of the Solid-Water Interface: Processes at the Mineral-Water and Particle-Water Interface in Natural Systems. John Wiley.
Sugimoto T., and Matijevic E. (1980) Formation of uniform spherical magnetite particles by crystallization from ferrous hydroxide gels. J. Colloid Interf. Sci. 74(1), 227-243.

Sundrehagen E. (1979) Formation and hydrolysation of ${ }^{99} \mathrm{Tc}(\mathrm{IV})$. Int. J. Appl. Radiat. Isot. 30, 739-749.

Tronc E., Belleville P., Jolivet J.-P., and Livage J. (1992) Transformation of ferric hydroxide into spinel by $\mathrm{Fe}^{\mathrm{II}}$ adsorption. Langmuir 8, 313-319.

Vichot L., Ouvrard G., Montavon G., Fattahi M., Musikas C., and Grambow B. (2002) XAS study of technetium(IV) polymer formation in mixed sulphate/chloride media. Radiochim. Acta 90, 575-579.

Wehrli B. (1990) Redox reactions of metal ions at mineral surfaces. In Aquatic Chemical Kinetics (ed. W. Stumm). John Wiley, pp. 311-336.

Wielinga B. W., Mizuba M. M., Hansel C. M., and Fendorf S. (2001) Iron promoted reduction of chromate by dissimilatory iron-reducing bacteria. Environ. Sci. Technol. 35, 522-527.

Wildung R. E., McFadden K. M., and Garland T. R. (1979) Technetium sources and behavior in the environment. $J$. Environ. Qual. 8, 156-161.

Wildung R. E., Gorby Y. A., Krupka K. M., Hess N. J., Li S. W., Plymale A. E., McKinley J. P., and Fredrickson J. K. (2000) Effect of electron donor and solution chemistry on products of dissimilatory reduction of technetium by Shewanella putrefaciens. Appl. Environ. Microb. 66(6), 2451-2460.

Wildung R. E., Li S. W., Murray C. J., Krupka K. M., Xie Y., Hess N. J., and Roden E. E. (2004) Technetium reduction in sediments of a shallow aquifer exhibiting dissimilatory iron reduction potential. FEMS Microbiol. Ecol. 49, 151-162.

Williams A. G. B., and Scherer M. M. (2004) Spectroscopic evidence for $\mathrm{Fe}(\mathrm{II})-\mathrm{Fe}(\mathrm{III})$ electron transfer at the iron oxidewater interface. Environ. Sci. Technol. 38, 4782-4790.

Williams A. G. B., Gregory K. B. F. P. G., and Scherer M. M. (2005) Hexahydro-1,3,5-trinitro-1,3,5-triazine transformation by biologically reduced ferrihydrite: evolution of $\mathrm{Fe}$ mineralogy, surface area, and reaction rates. Environ. Sci. Technol. 39, $5183-5189$.

Zachara J. M., Kukkadapu R. K., Fredrickson J. K., Gorby Y. A., and Smith S. C. (2002) Biomineralization of poorly crystalline $\mathrm{Fe}(\mathrm{III})$ oxides by dissimilatory metal reducing bacteria (DMRB). Geomicrobiol. J. 19(2), 179-207.

Zhao J., Huggins F. E., Feng Z., and Huffman G. P. (1994) Ferrihydrite: surface structure and its effects on phase transformations. Clays Clay Miner. 42, 737-746. 